*For correspondence: markus.thamm@uni-wuerzburg.de (MT)

\title{
Octopamine drives honeybee thermogenesis
}

3 Sinan Kaya-Zeeb ${ }^{1}$, Lorenz Engelmayer ${ }^{1}$, Jasmin Bayer ${ }^{2}$, Heike Bähre $^{3}$, Roland
${ }_{4}$ Seifert $^{3}$, Oliver Scherf-Clavel ${ }^{2}$, Markus Thamm $^{1 *}$

${ }_{5}^{1}$ Behavioral Physiology and Sociobiology, Julius Maximilian University of Würzburg, - Würzburg, Germany; ${ }^{2}$ Institute for Pharmacy and Food Chemistry, Julius Maximilian 7 University of Würzburg, Würzburg, Germany; ${ }^{3}$ Institute of Pharmacology, Research

\& Core Unit Metabolomics, Hannover Medical School, Hannover, Germany
Abstract In times of environmental change species have two options to survive: they either relocate to a new habitat or they adapt to the altered environment. Adaptation requires

physiological plasticity and provides a selection benefit. In this regard, the Western honeybee

(Apis mellifera) protrudes with its thermoregulatory capabilities, which enables a nearly worldwide distribution. Especially in the cold, shivering thermogenesis enables foraging as well as proper brood development and thus survival. In this study, we present octopamine signaling as a neurochemical prerequisite for honeybee thermogenesis: we were able to induce hypothermia by depleting octopamine in the flight muscles. Additionally, we could restore the ability to increase body temperature by administering octopamine. Thus we conclude, that octopamine is necessary and sufficient for thermogenesis. Moreover, we show that these effects are mediated by $\beta$ octopamine receptors. The significance of our results is highlighted by the fact the respective receptor genes underlie enormous selective pressure due to adaptation to cold climates. Finally, octopamine signaling in the service of thermogenesis might be a key strategy to survive in a changing environment.

\section{Introduction}

The Western honeybee (Apis mellifera) owns incredible thermoregulation strategies, which allow the colony to keep the brood area constantly at $34^{\circ} \mathrm{C}$ (Simpson, 1961). Due to this special feature, honeybees are relatively independent of the ambient temperature $\left(T_{A}\right)$, which may contribute decisively to their almost worldwide distribution (Wallberg et al., 2014). In contrast to other ectotherms, honeybee thermoregulation includes thermogenesis. Here, primarily workerbees actively increase their thorax temperatures ( $\mathrm{T}_{\mathrm{THX}}$, Kovac et al., 2009; Stabentheiner et al., 2010). This thermogenesis is of immense social importance, because it enables foraging at $\mathrm{T}_{A}$ below $10^{\circ} \mathrm{C}$ (Bujok et al., 2002; Stabentheiner et al., 2003) and a proper brood development (Himmer, 1932; Weiss, 1962; Tautz et al., 2003; Wang et al., 2016), reduces parasite infections (Starks et al., 2000; Campbell et al., 2010), and is a powerful defense mechanism against predatory hornets (Ken et al., 2005; Baracchi et al., 2010).

Workerbee thermogenesis is realized by the activation of the indirect flight muscles, formed by the dorsoventral wing elevators (DV) and the dorsal-longitudinal wing depressors (DL, Esch and Goller, 1991). However, these muscles are utilized in various other behaviors, which includes flight (Esch et al., 1975; Esch, 1976), fanning (Simpson, 1961) and communication during the waggle dance (Esch, 1961; Wenner, 1962). In order to perform these various tasks, diverse contraction mechanisms exist which must be controlled differently (Esch and Goller, 1991). Some evidence in- 
dicates a crucial role of octopamine in the insect flight muscles (Blau and Wegener, 1994; Blau et al., 1994; Wegener, 1996; Duch et al., 1999). Unfortunately, it remains unknown whether octopamine is used as a neurochemical in honeybee flight muscles or whether an octopamine receptor gene is expressed in these tissues. However, DL and DV are under control of the mesometa-thoracic ganglion (MMTG, Markl, 1966) and the octopaminergic innervation of the flight muscles seems to be a conserved feature in insects (Duch et al., 1999; Schlurmann and Hausen, 2003; Pauls et al., 2018). It was further demonstrated that the brain octopamine concentration of workerbees is significantly decreased due to cold stress (Chen et al., 2008), which indicates the temperature sensitivity of the neuronal octopaminergic system. In this context, Walllberg et al. (2017) made the observation that honeybee $\beta$ octopamine receptor genes (AmOARB1-3/4) are subject to altitudinal adaptation processes in honeybees. Yet, the physiological significance of this result has not been investigated so far. One important parameter that decreases significantly with increasing altitude is $T_{A}$. Consequently, honeybee thermogenesis is essential for colony survival, and the adaptive pressure on AmOARß1-3/4 may indicate the involvement of octopamine in this process.

We hypothesize that honeybee thermogenesis relies on octopamine signaling and that $\beta$ octopamine receptors are crucially involved in this process. We have investigated systematically the honeybee thoracic octopaminergic system. Moreover, we have tested our hypothesis and we can show that octopamine promotes thermogenesis by directly affecting the flight muscles.

\section{Results}

\section{Honeybee flight muscles are innervated by octopaminergic neurons}

First of all, we investigated whether octopamine can be a potential regulator of flight muscle functions in honeybees. Thus, we analyzed which monoamines are actually present in these tissues using high performance liquid chromatography (HPLC) together with an electrochemical detector (ECD). We can detect octopamine and dopamine in both, DV and DL, whereas serotonin and tyramine are not detectable (Figure 1A, Figure Supplement 1A). We further compared the flight muscle octopamine concentration in differently aged workerbees. Newly emerged bees which cannot perform thermogenesis have the lowest octopamine concentration in DV and DL (Figure 1A-B) and the octopamine concentration increases with the age of the workerbee (Figure 1A-B). In contrast to octopamine, the concentrations of dopamine have a different time course in DV and DL (Figure Supplement 1B-C). We have further analyzed the MMTG. In addition to octopamine, serotonin, dopamine, and tyramine are also detectable, but no no age-related differences can be observed for any of these monoamines (Figure 1C, Figure Supplement 1D-F).

Nerves originating from the MMTG exclusively innervate the honeybee flight muscles (Markl,
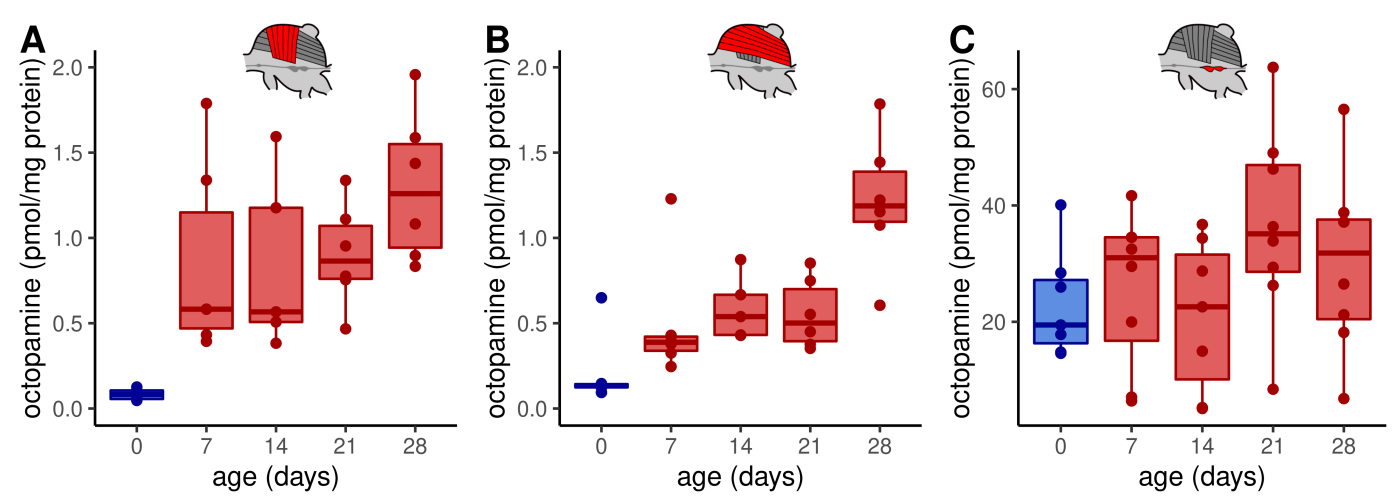

Figure 1. Octopamine concentrations in thoracic tissues across age. Octopamine concentrations differ significantly between different workerbee age groups in DV (A) and DL (B) but not in the MMTG (C). blue = no active heating, red = active heating. Shown is median \pm interquartile range (IQR). For statistics see Table 1.

Figure 1-Figure supplement 1. Monoamine quantification with HPLC-ECD in workerbee thoracic tissues. 
bioRxiv preprint doi: https://doi.org/10.1101/2021.11.04.467276; this version posted November 6, 2021. The copyright holder for this preprint (which was not certified by peer review) is the author/funder, who has granted bioRxiv a license to display the preprint in perpetuity. It is made available under aCC-BY 4.0 International license.

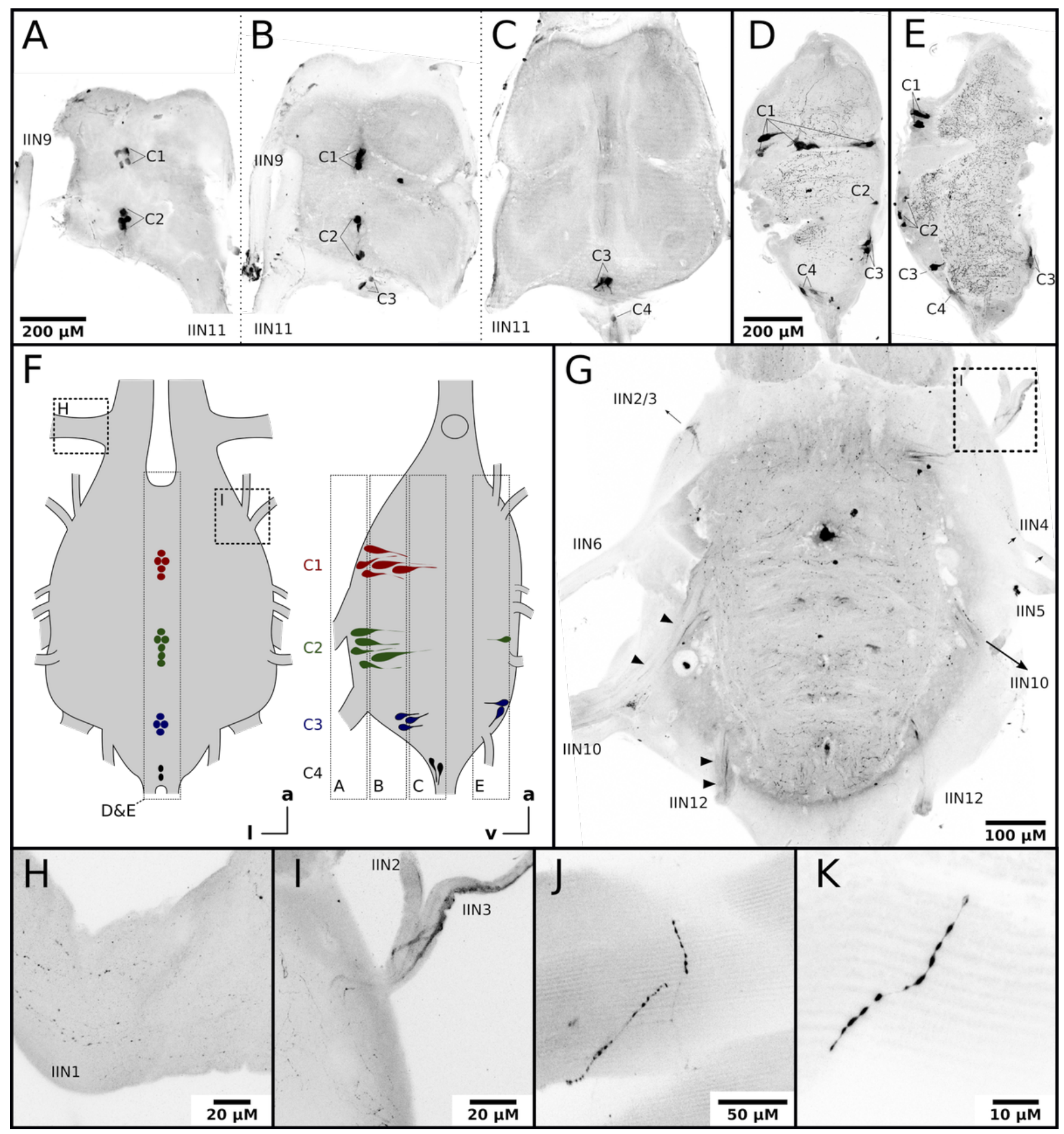

Figure 2. Honeybee flight muscles are innervated by octopaminergic neurons.

A-E) Different cell clusters with OA-IR are observable. Consecutive frontal sections of the MMTG of the same workerbee (A-C) beginning with the most ventral section (A) showing clusters of OA-IR positive cells (C1-C4). Sagital sections (D-E) in the midline area of the MMTG of two individual bees display the same OA-IR positive cell clusters.

F) Schematic interpretation of the location of the cell clusters found in A-E. Additionally, the approximate location of frontal sections (A-C, $G$ ), the sagital sections (D-E), and the detailed images $(\mathrm{H}-\mathrm{I})$ are indicated by dashed boxes.

G) Dorsally located frontal section of the MMTG in showing several nerves which are leaving the ganglion. Strong OA-IR positive fibers run into the nerves IIN3, IIN10 and IIN12 (arrowheads).

H) Within the nerve IIN1 fine varicose structures with OA-IR are observable.

I) An OA-IR positive axon bundle runs through the nerve IIN3.

J-K) Flight muscle preparations reveal fine varicose structures with OA-IR closely attached to muscle fibers. 
1966; Pan, 1980). To answer whether octopamine in DV and DL can be delivered directly by octopaminergic neurons from the MMTG we used an octopamine specific antibody to analyze the octopamine distribution in these tissues. Octopamine-like immunoreactivity (OA-IR) is observable in four individual cell clusters, with most of the cell bodies being found at the ventral midline (Figure 2A-E). Some OA-IR positive cell bodies are also located at the dorsal midline (Figure 2DE). Most MMTG leaving nerves show OA-IR (Figure 2G-I), as varicose fibers in IIN1 and a thicker axonal bundle in IIN3 demonstrate (Figure 2G,I). Finally, finest OA-IR positive varicose structures can be found directly at muscle fibers (Figure 2J-K).

\section{AmOAR $\beta 2$ is expressed in the flight muscles}

We next determined which octopamine receptor genes are expressed in the workerbee flight muscle. The honeybee genome harbors five different genes that code for octopamine receptors and two additional genes encoding tyramine receptors. The respective receptor proteins are functionally characterized (Blenau et al., 2000; Grohmann et al., 2003; Balfanz et al., 2013; Reim et al., 2017; Blenau et al., 2020). We observe strong signals for PCR products for AmOARa1 and AmOAR $\beta 2$, weak DNA bands for $A m O A R \beta 1$ and $A m O A R B 3 / 4$, and no amplification product in the case of $A m O A R a 2$ and both tyramine receptor genes (AmTAR1 \& AmTAR2; Figure 3A). In addition, PCR products indicate the expression for all known honeybee octopamine and tyramine receptor genes in neural tissues (brain, MMTG).

We further determined the relative gene expression of the most promising candidates by quantitative Real Time PCR (qPCR, Figure 3B-E). AmOARa1 and AmOARß2 expression can be observed in $D V$ and $D L$ in all age groups of workerbees. Here, relative expression increases with age, as shown by significant differences between newly emerged bees ( 0 days) and the three oldest groups.

A

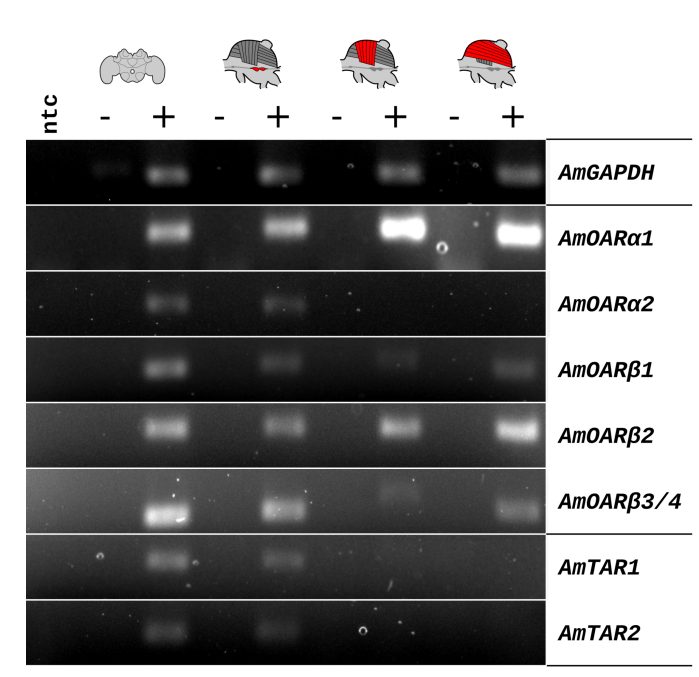

B AmOARo1

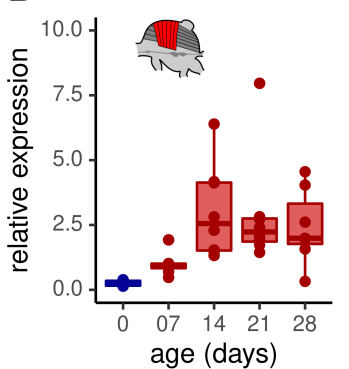

D AmOARB2

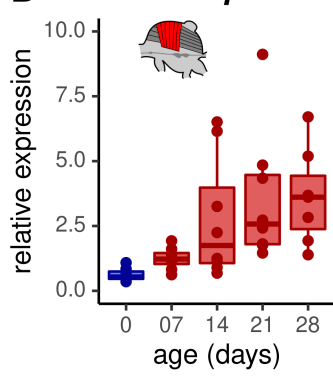

C AmOAR 1

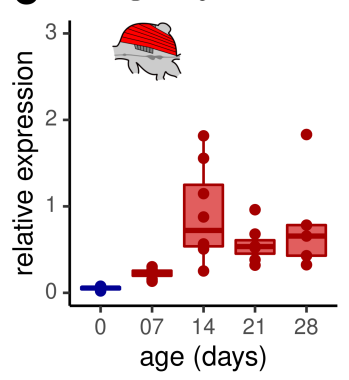

E AmOARB2

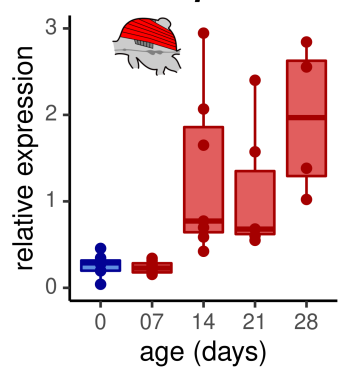

Figure 3. Octopamine receptor expression in the flight muscles.

A) Brain, MMTG, DV and DL were manually dissected from workerbees and underwent subsequent RNA isolation, CDNA synthesis and PCR analysis (+). The reverse transcriptase was omitted during CDNA synthesis for negative controls (-). RNase free water serves as no template (ntc) and AmGAPDH as loading control. B-E) AmOARa1 and AmOARB2 expression in DV and DL of differential aged workerbees with (red) or without (blue) the capability for thermogenesis. Data are represented as boxplots. Shown is median \pm IQR. For statistic see Table 2. 


\section{Octopamine is mandatory for honeybee thermogenesis}

To investigate the consequences of octopamine missing in the flight muscles, we fed workerbees with reserpine. This drug has the ability to deplete vesicles on monoaminergic synapses (Plummer et al., 1954; Cheung and Parmar, 2020). The octopamine concentrations in DV and DL are significantly decreased due to our treatment (Figure 4A-B). In contrast, the dopamine concentration in the flight muscle seems not to be affected (Figure Supplement 1). The same is true for the concentrations of octopamine (Figure $4 \mathrm{C}$ ) and of the other monoamines in the MMTG (Figure Supplement 1).

The reserpine feeding additionally causes hypothermia in both, nurse bees and forager bees (Figure 4D, Table 3). A preliminary screen with serotonin, dopamine, octopamine and tyramine revealed, that octopamine may reverse the reserpine effect (Figure Supplement 2). We were able to show that this octopamine effect is robust. We reversed the reserpine induced hypothermia by injecting octopamine directly into the flight muscles (Figure 4D, Table 3).
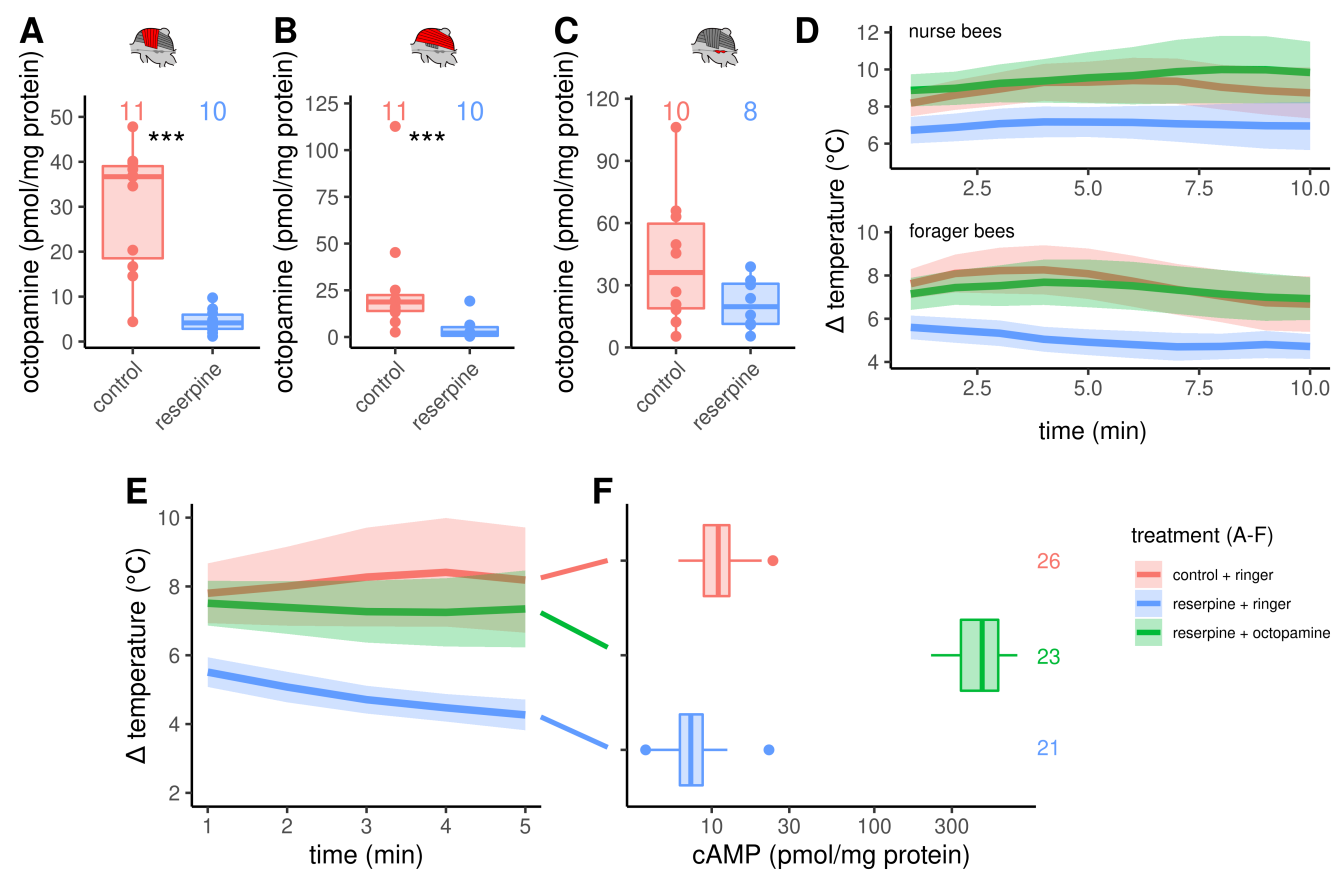

Figure 4. Octopaminergic control of honeybee thermogenesis.

A-C: Octopamine concentrations are decreased in DV and DL but not MMTG of reserpinezed workerbees. Data are represented as boxplots. Shown is median $\pm I Q R$.

Mann-Whitney $U$ test, DV(A): $W=105, z=-3.70, p=0.0001 ; D L(B): W=102, z=-3.37, p=0.0004 ; M M T G(C)$ : $W=56, z=-0.94, p=0.1728$.

D: Reserpinezed bees show hypothermia when compared with control. An injection of octopamine into the flight muscle helps the bees to recover, as no differences are observable between the control group and the recovered bees. The solid line represents the mean difference between $\mathrm{T}_{\mathrm{THX}}$ and $\mathrm{T}_{\mathrm{A}}$ and the shaded area represents the $95 \%$ confidence interval. For statistic see Table 3.

E) Similar experiment as in D) but bees were frozen in liquid $\mathrm{N}_{2}$ after 5 min for CAMP quantification. For statistic see Table 3.

F) The tissue cAMP concentrations in the flight muscles differ significantly due the treatment (Kruskal-Wallis test, $\chi^{2}=52.636, d f=2, p=0.000000000004$ ). Reserpinezed bees has the lowest tissue cAMP concentrations in the flight muscles when compared with controls (Dunns test, $Z=2.6383, p_{a d j}=0.025$ ) and recovered bees $\left(Z=7.117, p_{a d j}=0.000000000003\right)$. Controls also differ from the recovered bees $\left(Z=-4.7998, p_{a d j}=0.000005\right)$. Data are represented as boxplots. Shown is median \pm IQR.

Figure 4-Figure supplement 1. The effect of reserpine on monoamine concentrations in DV, DL and MMTG. Figure 4-Figure supplement 2. The effect of different monoamines on thermogenesis of reserpinized bees. Figure 4-Figure supplement 3. The effect of reserpine on flight muscle cGMP concentrations. 
As stated above, we hypothesize that $\beta$ octopamine receptors are crucially involved in honeybee thermogenesis. Via $\mathrm{Ga}_{\mathrm{s}}$ proteins, these receptors are positively coupled to membrane-bound adenylyl cyclases (mAC), which leads to an increase of the intracellular adenosine 3',5'-cyclic monophosphate (CAMP) concentration upon receptor activation (Balfanz et al., 2013). To control our hypothesis, we have repeated the reserpine experiment reported above. The reserpine induced hypothermia as well as the octopamine reversion of this effect are again clearly observable (Figure $4 \mathrm{E}$, Table 3). We stopped thermography after $5 \mathrm{~min}$ and the bees were immediately flash-frozen to subsequently quantify the tissue CAMP concentrations of their flight muscles. The tissue CAMP concentration is significant lower in reserpinized bees when compared with control (Figure 4D). Furthermore, octopamine injection into the flight muscles of reserpinized bees leads to a strong increase of the tissue cAMP concentration (Figure 4D). The tissue guanosine 3',5'-cyclic monophosphate (CGMP) concentrations seem not to be affected by our treatment (Figure Supplement 3). Further cyclic nucleotides in the flight muscles were either below the lower limit of quantification (cytidine 3',5'-cyclic monophosphate, cCMP) or were not detectable at all.

\section{Octopamine receptor antagonists also induce hypothermia}

In a final experiment series, we aimed to confirm the described effects of octopamine on honeybee thermogenesis and also to further narrow down the responsible receptor subtypes. Therefore, we injected different pharmacological substances directly into the flight muscles and analyzed their effect on thermogenesis. These substances antagonize various octopamine, tyramine, or adrenergic receptors. All antagonists either lead to hypothermia in both, nurse bees and forager bees, or they are not effective at all. The non-selective but potent octopamine receptor antagonist mianserin leads to hypothermia (Figure 5A, Table 3), while the effective tyramine receptor and a octopamine receptor antagonist yohimbine does not (Figure 5B, Table 3). Finally, alprenolol causes hypothermia too (Figure 5C, Table 3), whereas carvedilol and metoprolol did not have an observable effect on thermogenesis (Table 3).
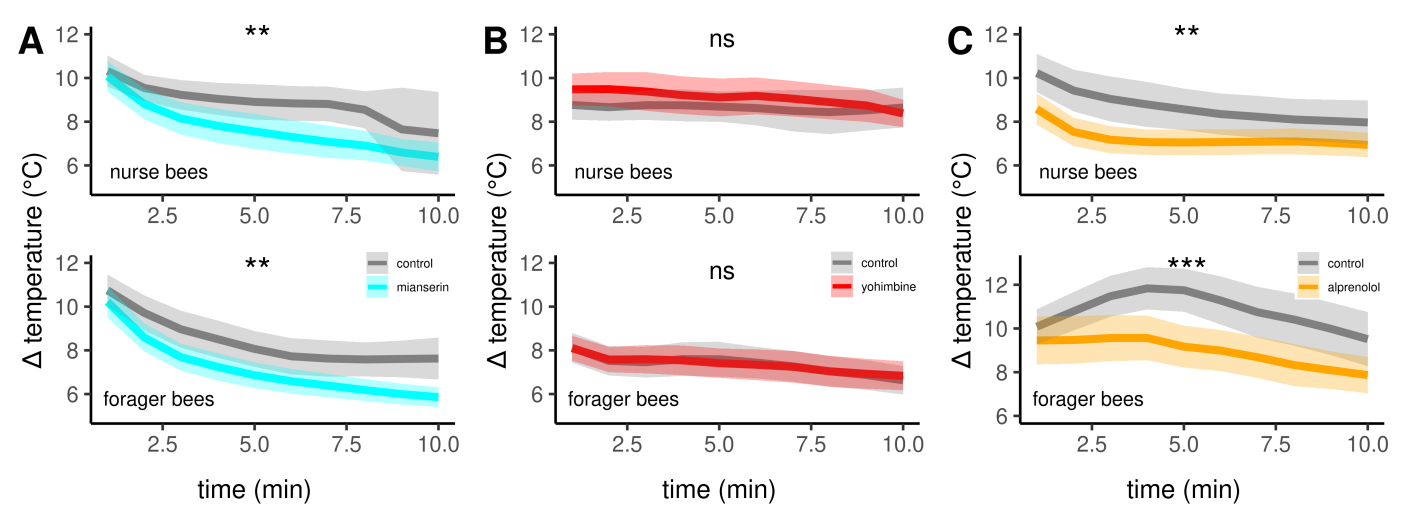

Figure 5. The effects of different antagonists on workerbee thermogenesis.

Mianserin (A) and alprenolol (C) cause hypothermia in workerbees but not yohimbine (B). The solid line represents the mean difference between $\mathrm{T}_{\mathrm{THX}}$ and $\mathrm{T}_{\mathrm{A}}$ and the shaded area represents the $95 \%$ confidence interval. For statistic see Table 3.

\section{Discussion}

In this study, we hypothesized that octopamine has a critical role in the shivering thermogenesis of honeybees. An important prerequisite is that this monoamine can be used as a neurochemical substance at the flight muscles, which seems to be a conserved feature in insects (Duch et al., 1999; Schlurmann and Hausen, 2003; Pauls et al., 2018). We can demonstrate that octopamine is present in workerbee flight muscles by independent analysis methods (HPLC-ECD, antibody labeling). This is most likely delivered via flight muscle innervating neurons from the MMTG. Here, we can detect 
four octopaminergic cell clusters. Those are known to derive from a single median neuroblast at the posterior border of each segment of the developing neuroectoderm and are then displaced during the fusion of ganglia to the dorsal or the ventral surface (Bräunig and Pflüger, 2001). We postulate that the octopaminergic cells in each cluster we found are descendants of individual neuroblasts of their neuromere. The honeybee MMTG is formed by fusion of four neuromers (mesothorax, methathorax, first and second abdominal ganglia; Markl, 1966). Furthermore, the MMTG nerves IIN1 and IIN3 innervate DV and DL, respectively (Markl, 1966; Pan, 1980), while some of their neuronal structures contain octopamine. Finally, they reach DV and DL as octopaminergic varicosities suggest. We conclude, that octopaminergic neurons from the MMTG directly innervate the flight muscles and therefore influence thermogenesis.

If this is true, octopamine should be detectable at comparable concentrations in the flight muscles of workerbees capable of thermogenesis. Indeed, we found no differences in bees with ages ranging from seven days up to four weeks. They are all similarly engaged in active heat production independent of their actual task within the colony (Stabentheiner et al., 2010). In contrast, newly emerged bees, which are not capable of heat production (Harrison, 1987; Stabentheiner et al., 2010), have significant lower flight muscle octopamine concentrations. It remains uncertain whether there is a causal relationship between the low octopamine concentrations and the absence of thermogenesis in newly emerged bees or whether this observation is merely a correlation. Several factors could be responsible, such as incomplete differentiation of flight muscle tissues (Roberts and Elekonich, 2005; Correa-Fernandez and Cruz-Landim, 2010).

We determined AmOARa1 and AmOARB2 as the predominant octopamine receptor genes expressed in the flight muscle, and their expression is detectable across age. The relative expression of both genes is higher in older bees, but at the same time a huge inter-individual variation is detectable. This might reflect differential demands to muscle activity in the context of the agedependent task allocation and its neurochemical control. Workerbees perform very different tasks as a function of their age (Seeley, 1995). Yet, they are all similarly engaged in heat production if they are older than two days (Stabentheiner et al., 2010). Besides flight and thermogenesis another important function of the flight muscles is fanning for cooling purposes (Hess, 1926; Hazelhoff, 1954; Simpson, 1961) and octopamine is known to increase the probability of fanning when fed to workerbees together with tyramine (Cook et al., 2017). The two genes AmOARa1 and AmOARB2 encode the octopamine receptor proteins AmOARa1 (Grohmann et al., 2003) and AmOARß2 (Balfanz et alo, 2013), respectively. We assume, that both receptors can receive and forward the signal mediated by an octopamine release at the flight muscles. Until now, we did not know in which situations this occurs and what specific role the corresponding receptors might have in this process.

Our reserpine experiments solve this problem, because it makes octopamine no longer usable at the flight muscle. As direct consequence, we observe hypothermia. Moreover, if we supply the system with octopamine again we can restore heat generation. We conclude that octopamine is necessary and sufficient for honeybee thermogenesis. This interpretation is supported by the fact that the potent octopamine receptor antagonist mianserin (Grohmann et al., 2003; Balfanz et al., 2013; Blenau et al., 2020) causes hypothermia, too. Moreover, our cAMP quantification result suggests that $\beta$ octopamine receptors mediate the octopamine signal in the service of thermogenesis. The decreased octopamine availability in the flight muscles of reserpinezed bees likely causes the loss of octopamine release if necessary. In the end, this results in a reduction of octopamine receptor activation events. In the case of $\beta$ octopamine receptors, consequently, no CAMP is produced. Indeed, we observe a decrease in tissue CAMP concentrations in combination with reserpine induced hypothermia. Octopamine-induced reversal of this effect is accompanied by a tremendous increase in tissue cAMP concentrations. Unfortunately, honeybee CAMP concentrations from muscle tissues are not available, but our results are consistent with analysis in locust flight muscle (Baines et al., 1990; Lange and Nykamp, 1996). Furthermore, the lack of an octopamine effect on cGMP concentrations and the absence of the other cyclic nucleotides clearly 
suggests that mACs mediate the observed octopamine effects. Hasan et al. (2014) could show that mAC activation leads to exclusive CAMP increase. Our results strongly suggests that $\beta$ octopamine receptor activation is necessary for honeybee thermogenesis, since these receptors are known to be positively coupled mACs (Balfanz et al., 2013). Our explanation again receives support by pharmacological thermography. Due to the lack of sub-type specific octopamine receptor antagonists, we made use of well-established adrenoceptor antagonists. Deuterostome adrenoceptor and arthropoda octopamine receptors are very closely related (Roeder, 2005; Spindler et al., 2013; Fuchs et al., 2014; Hochman, 2015; Roeder, 2020), which also applies to receptor sub-types as supported by phylogenetic analyses (Qi et alo, 2017). The reserpine and mianserin effects described above can be mimicked by alprenolol (Figure $5 \mathrm{G}$ ). This antagonist is active at both, $\beta 1$ and $\beta 2$ adrenoceptors (Ablad et al., 1972, 1973). Therefore, it represents a putative antagonist of AmOARß1 and AmOARß2 and was already used in insects in other studies (Belzunces and Gu, 1996; Cossío-Bayúgar et al., 2012). Contrastly, carvedilol and metoprolol did not cause any effect. Carvedilol antagonizes preferably a 1 and $\beta 1$ adrenoceptors (Hansson and Himmelmann, 1998), whereas metoprolol antagonizes $\beta 1$ adrenoceptors in the human heart (Benfield et al., 1986). We assume that both substances antagonize the corresponding octopamine receptors. Several studies show that metoprolol is effective in species belonging to all major protostome phyla (Dzialowski et al., 2006; Spindler et al., 2013; Jungmann et al., 2016; Buchberger et al., 2018). However, an expansion of the pharmacological profiles of honeybee octopamine receptors (Grohmann et al., 2003; Balfanz et al., 2013; Blenau et al., 2020) is needed to confirm whether the compounds we used actually antagonize the desired receptor proteins. Combining these information with our result that alprenolol causes hypothermia in workerbees and that the AmOARß2 gene is predominantly expressed in the flight muscles, we conclude that AmOAR 32 is crucially involved in honeybee thermogenesis. Interestingly, with the $\beta 2$ adrenergic receptor mammals express a similar receptor subtype as the predominant adrenoceptor in their skeletal muscle tissue (Liggett et alo, 1988; Kim et al., 1991).

Our PCR analysis further revealed the prevalent expression of AmOARa1. However, yohimbine does not cause hypothermia. This substance was shown to bind and antagonize a1 octopamine receptors receptors in a wide range of insects (Bischof and Enan, 2004; Enan, 2005; Ohtani et al., 2006; Huang et al., 2010). Thus, we hypothesize that this receptor is not in the service of thermogenesis.

Tyramine is also capable to reverse the reserpine induced hypothermia. However, we could observe neither tyramine nor any tyramine receptor gene expression in the flight muscles. One might argue that the tyramine effect is mediated via tyramine receptors that are expressed in the MMTG. In that case, the potent tyramine receptor antagonist yohimbine (Ohta et al., 2003; Fussnecker et al., 2006; Reim et al., 2017) should have an effect on thermogenesis, but this is not the case. Based on our results and the fact that tyramine is able to activate octopamine receptors (Grohmann et al., 2003; Balfanz et al., 2013; Blenau et al., 2020), we classify this tyramine effect as artificial and physiologically not relevant.

The data of our study supports the hypothesis that octopamine is necessary and sufficiant for honeybee thermogenesis. Most likely, this monoamine acts directly at the indirect flight muscles via the activation of AmOAR 32 . We speculate, that the role of octopamine and its receptor AmOARß2 is to boost glycolysis (see scheme Figure 6). Cold stress will induce an octopamine release directly at the flight muscles. The subsequent AmOAR 32 mediated generation of CAMP will activate proteinkinase A (PKA, Müller, 2000). PKA in turn phosphorylates and activates phosphofructokinase 2 (PFK-2), which is the enzyme that produces fructose-2,6-bisphosphate $\left(\mathrm{F} 2,6 \mathrm{P}_{2}\right.$, Rider et al., 2004). $\mathrm{F} 2,6 \mathrm{P}_{2}$ is an activity increasing modulator of phosphofructokinase 1 (PFK-1, Hue and Rider, 1987; Bartrons et al., 2018). The PFK-1 mediated phosphorylation of fructose-6-phosphate (F6P) to fructose-1,6-bisphosphate $\left(\mathrm{F}_{\left.1,6 \mathrm{P}_{2}\right)}\right)$ is a key step in glycolysis, at its end ATP is provided (Fothergill-Gilmore and Michels, 1993). Finally, heat is generated by the hydrolysis of ATP at the 


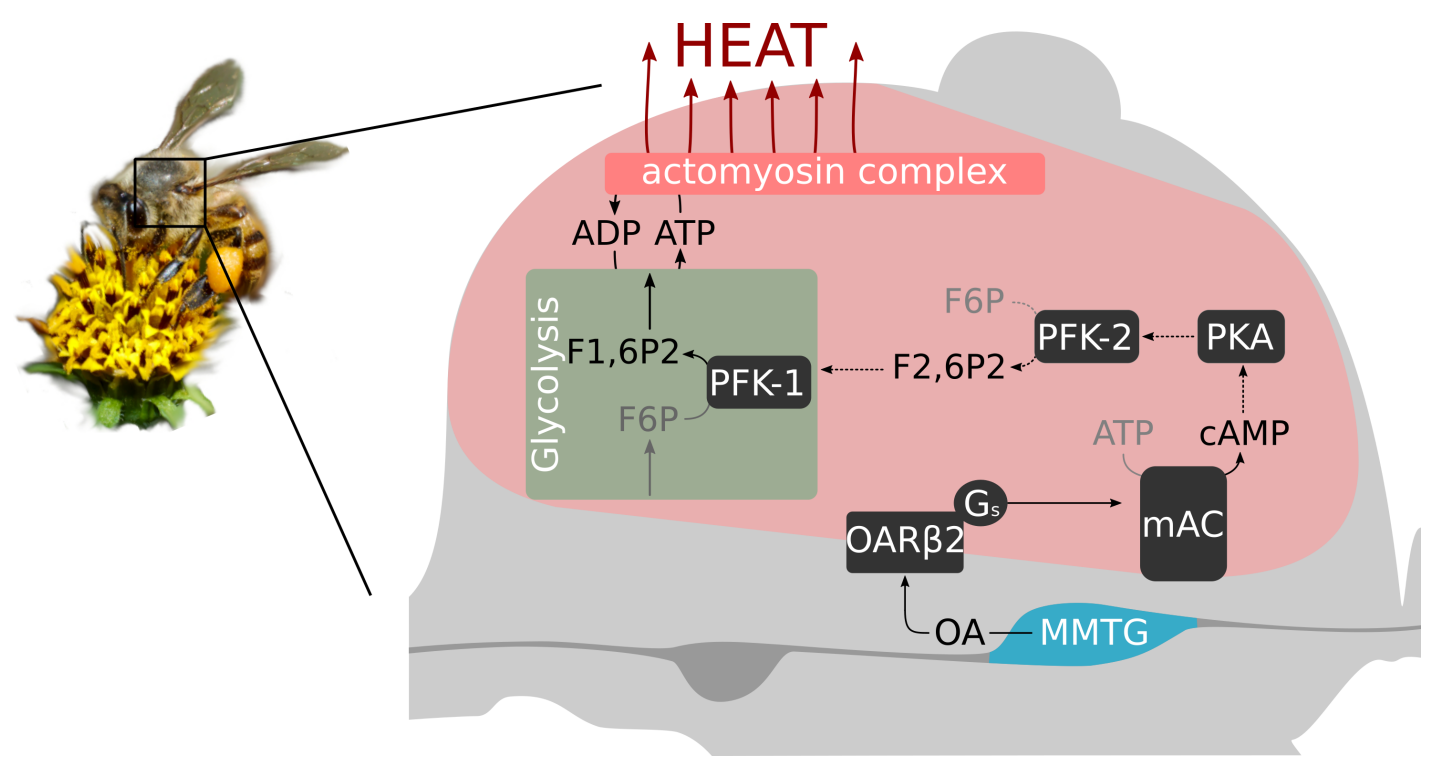

Figure 6. Octopamine and honeybee thermogenesis. The scheme summarizes our findings, with the solid lines representing interpretations supported by our results and the dashed lines representing hypothetical pathways. Muscle innervating neurons in the MMTG release octopamine (OA) directly to the flight muscles. By this, AmOAR 22 receptors are activated which in turn activate the membrane-bound adenylyl cyclase (mAC) via $G_{S}$ proteins. The resulting increase in the intracellular CAMP concentration leads to the activation of Proteinkinase A (PKA) which phosphorylates and by this activates phosphofructokinase 2 (PFK-2). Consequently, this enzyme produce fructose-2,6-bisphosphate (F2,6P2) which increases the activity of phosphofructokinase 1 (PFK-1) and through this the output of glykolysis. Finally, heat is generated at the actomyosin complex.

actomyosin complex (Zhang and Feng, 2016). The alternative futile cycle (Newsholme et al., 1972), which is based on high fructose-1,6-bisphosphatase (FbPase) activity in certain bumblebee species, must be doubted, at least for honeybees. Honeybees and many other bumblebee species have comparable low FbPase activity (Newsholme and Crabtree, 1970; Staples et al., 2004) and FbPasePFK cycling rates are not sufficient for heat production (Clark et al., 1973; Kammer and Heinrich, 1978; Newsholme and Crabtree, 1976). Our hypothetical cascade is supported by the results of other studies. $\mathrm{F2}, 6 \mathrm{P}_{2}$ levels increase in locust flight muscles due to octopamine stimulation (Blau and Wegener, 1994; Blau et al., 1994) and by this controls the rate of carbohydrate oxidation in flight muscles (Wegener, 1996). In mammals, adrenaline stimulates increasing $F 2,6 \mathrm{P}_{2}$ levels and thus glycolysis (Narabayashi et al., 1985). This effect is achieved by $\beta$ adrenoreceptor activation followed by stimulation of PKA (Rider et al., 2004). Chronic exercise causes stereotypical adaptations in several tissues of Drosophila melanogaster, which requires the activation of octopaminergic neurons (Sujkowski et al., 2017). In muscles, those effects are dependent on the activation of $\beta$ octopamine receptors (Sujkowski et al., 2020). If cold stress becomes chronic, such as in cold climate at high altitude or during winter, there will probably be a similar pattern in honeybees. It is conceivable that the octopaminergic system in the flight muscles is permanent active to enable persistent heat production. If this system is compromised, it will endanger the survival of the colony due to the lost of individually performed heating, which enables foraging, breeding, and diverse defense mechanisms (Himmer, 1932; Weiss, 1962; Starks et al., 2000; Bujok et al., 2002; Stabentheiner et al., 2003; Tautz et al., 2003; Ken et al., 2005; Baracchi et al., 2010; Campbell et al., 2010; Wang et al., 2016). This may explain the enormous selective pressure on $\beta$ octopamine receptor genes (Wallberg et al., 2017). Issues to be addressed are how the system responds to short and long term cold stress. But also heat stress, and in this context adaptations to warm climate in the course of climate change can become very important. With our important contribution to the understanding of thermogenesis in honeybees we provide a solid basis to analyze these issues. 


\section{Methods and Materials}

\section{Animals}

Honeybee workers (Apis mellifera carnica) were collected from colonies of the department next to the Biocenter at the University of Würzburg, Germany. We declared bees that returned to the hive with pollen loads on their hind legs as forager bees. As nurse bees, we defined bees, that were sitting on a brood comb and were actively heating (thorax temperature, $\mathrm{T}_{\mathrm{THX}} \geq 32{ }^{\circ} \mathrm{C}$ ). $\mathrm{T}_{\mathrm{THX}}$ was monitored with a portable thermographic camera (FLIR E6, FLIR, Wilsonville, USA). Pollen forager were collected for the gene expression analysis from the same hives and were immediately flashfrozen in liquid nitrogen and stored at $-80^{\circ} \mathrm{C}$. For the age-series analysis (monoamine quantification, gene expression analysis), a queen was caged on a brood comb for 3 days. Shortly before the bees started to emerge, we transferred the brood comb into an incubator $\left(34{ }^{\circ} \mathrm{C}, \mathrm{RH}=65 \%\right.$ ). The first group (0-day-old bees) consisted of newly hatched bees and were collected directly from the brood comb. The remaining newly hatched bees were color-marked and then inserted into a standard hive. Those bees were collected from the hive after 7, 14, 21, and 28 days, respectively. All collected bees were immediately flash-frozen in liquid nitrogen and subsequently stored at $-80^{\circ} \mathrm{C}$.

\section{Immunohistochemistry}

For octopamine immunolabeling we used a polyclonal rabbit anti-octopamine antibody (IS1033, ImmuSmol, Bordeaux, France) together with the STAINperfect immunostaining kit A (SP-A-1000, ImmuSmol, Bordeaux, France). We have analyzed ten individual MMTGs in three independent experiments for frontal sections and additionally three individual MMTGs for sagital sections. Four individual DVs and DLs, respectively, were analyzed in two independent experiments. Due to non optimal tissue permeability, we have slightly adopted the manufacturers protocol for whole mount preparations to perform analysis with vibratom sections. In brief, tissues (MMTG, flight muscles) were micro-dissected and subsequently fixed in fixation buffer for $3 \mathrm{~h}$ at $4{ }^{\circ} \mathrm{C}$ while shaking. Afterwards, the fixed tissues were washed five times for 30 min with Wash Solution 1, embedded in $5 \%(w / v)$ agarose and were cut into $100 \mu \mathrm{m}$ thick sections. Then, the tissue sections were treated consecutively: $1 \mathrm{~h}$ in Permeabilization Solution at RT followed by two times Wash Solution 1 for $3 \mathrm{~min}, 1 \mathrm{~h}$ in Stabilization Solution followed by three times Wash Solution 1 for 3 min, and $1 \mathrm{~h}$ in Saturation Solution at RT. Afterwards, the Saturation Solution was replaced by the primary antibody (1:500, in Antibody Diluent) and the tissue sections were incubated at $4{ }^{\circ} \mathrm{C}$ while shaking for at least for $72 \mathrm{~h}$. After five times washing cycles with Wash Solution 2 for 30 min at RT the secondary antibody (1:200 in Antibody Diluent, goat anti-rabbit Alexa Fluor 568; Molecular Probes, Eugene, USA) was applied for $24 \mathrm{~h}\left(4^{\circ} \mathrm{C}\right)$. After the final washing with Wash Solution 2 and Wash Solution 3 (both 3 times for 30 min at RT) the slices were mounted in 80 \% Glycerol (in Wash Solution 3) on microscope slides. Preparations were imaged by confocal laser scanning microscopy using a Leica TCS SP2 AOBS (Leica Microsystems AG, Wetzlar, Germany). HC PL APO objective lenses (10x/0.4 NA imm; 20x/ 0.7 NA imm and 63x/1.20 NA imm) with additional digital zoom were used for image acquisition. Imagej (1.53c, Schindelin et al., 2012) was used to process images (maximum intensity projection, optimization for brightness and contrast) and Inkscape (1.1, Inkscape Developer Team, 2021) was used to arrange images into figures. MMTG nerve terminology is based on the nomenclature used by Markl (1966).

\section{Monoamine quantification}

The DV and DL were dissected under liquid nitrogen. Afterwards, we thawed the remaining thoracic tissue in ice-cold ethanol to immediately dissect the MMTG. The separated tissues were kept at $-80^{\circ} \mathrm{C}$ until extraction. For high performance liquid chromatography (HPLC) analysis of the monoamines we used a slightly modified protocol as described by Cook et al. (2017). For extraction, $120 \mu \mathrm{L}(\mathrm{DV}, \mathrm{DL})$ or $60 \mu \mathrm{L}$ (MMTG) of extraction solution (10.0 pg/ $\mu \mathrm{L}$ 3,4-dihydroxy-benzylamine (DHBA) in $0.2 \mathrm{M}$ perchloric acid) was added in the first step. After a short centrifugation (21,130 g, 
$2 \mathrm{~min}, 0^{\circ} \mathrm{C}$ ) the tissues were disintegrated via sonication $\left(10 \mathrm{~min}, 0{ }^{\circ} \mathrm{C}\right)$, followed by an incubation $\left(20 \mathrm{~min}, 0^{\circ} \mathrm{C}\right)$. After a final centrifugation $\left(21,130 \mathrm{~g}, 14 \mathrm{~min}, 0^{\circ} \mathrm{C}\right)$, the supernatant was analyzed via HPLC-ECD (Thermo Fisher Scientific, Waltham, USA) and the pellet was stored at $-80^{\circ} \mathrm{C}$ for protein quantification. A $3 \mu \mathrm{m}$ reverse phase column (BDS-Hypersil-C18, $150 \times 3 \mathrm{~mm}$, pore size $130 \AA$, Thermo Fisher Scientific, Waltham, USA) and an ECD-3000RS configuration with two coulometric cells (6011RS ultra-analytical cell, Thermo Fisher Scientific, Waltham, USA) were connected to a biocompatible Dionex Ultimate 3000 UHPLC focused (Thermo Fisher Scientific, Waltham, USA). The mobile phase contained $15 \%(\mathrm{v} / \mathrm{v})$ methanol, $15 \%(\mathrm{v} / \mathrm{v})$ acetonitrile, $85 \mathrm{mM}$ sodium phosphate monobasic, $1.75 \mathrm{mM}$ sodium dodecyl sulfate, $0.5 \mathrm{mM}$ sodium citrate and ultrapure water. Phosphoric acid was used for accurate $\mathrm{pH}$ adjustment $(\mathrm{pH} 5.6+/-0.01$ ). We used a flow rate of $0.5 \mathrm{~mL} / \mathrm{min}$. Two detector channels were connected in series with working potentials of $425 \mathrm{mV}$ (DHBA, dopamine, serotonin) and $800 \mathrm{mV}$ (octopamine, tyramine), respectively. Quantification was performed via an external calibration. The raw data analysis was carried out with the program Chromeleon (7.2.10, Thermo Fisher Scientific, Waltham, USA).

\section{Quantitative analysis of cyclic nucleotides}

Individual flight muscle tissues were dissected under liquid nitrogen. Individual DV and DL were pooled and $800 \mu \mathrm{L}$ homogenization buffer (40\% (v/v) acetonitrile, 40\% (v/v) methanol, 20\% (v/v) $\mathrm{H}_{2} \mathrm{O}$ ) was added and homogenized as described above. Samples were incubated at $95{ }^{\circ} \mathrm{C}$ for $10 \mathrm{~min}$ and then stored in the freezer $\left(-80^{\circ} \mathrm{C}\right)$ until further processing. After centrifugation (10 min, $21,130 \mathrm{~g})$, the supernatant was transferred to mass spectroscopic analysis (HPLC-MS) as described by Beste et al. (2012). The residual pellet was used for the protein quantification.

\section{Protein quantification}

To compensate possible differences in the accuracy of tissue dissection for the HPLC-ECD and HPLC-MS analysis, we additionally measured the protein content in the samples after Bradford (Fic et al., 2010) and normalized amine or cyclic nucleotide concentration to protein content. The pellet (see above) was resuspended in $120 \mu \mathrm{L}$ (HPLC-ECD: DV, DL), $30 \mu \mathrm{L}$ (HPLC-ECD: MMTG) or 500 $\mu \mathrm{L}$ (HPLC-MS: DV+DL) $0.2 \mathrm{M} \mathrm{NaOH}$. After an incubation ( $15 \mathrm{~min}, 0^{\circ} \mathrm{C}$ ) the insoluble material was sedimented (9,391 g, 5 min). Finally, $2 \mu \mathrm{L}$ (HPLC-ECD: DV, DL), $10 \mu \mathrm{L}$ (HPLC-ECD: MMTG) or 2,5 $\mathrm{HL}$ (HPLCMS: DV+DL) of the supernatant were transferred into a final volume of $1 \mathrm{~mL} 1 \times \mathrm{ROTI}{ }^{\circledR} \mathrm{Nanoquant}$ solution (Carl Roth, Karlsruhe, Germany). All samples and the external calibrator (1, 2, 3, 5, 10, $20 \mu \mathrm{g} / \mathrm{mL}$ Albumin Fraction V, Carl Roth, Karlsruhe, Germany) were analyzed with a plate reader (Infinite 200 Pro, Tecan, Männedorf, Switzerland).

\section{Gene expression analysis}

Individual flight muscle tissues were dissected under liquid mitrogen. For the MMTG we have used RNAlater ICE (Thermo Fisher Scientific, Waltham, USA) to prevent RNA degradation during the dissections. The GenUP Total RNA Kit (biotechrabbit, Henningsdorf, Germany) was used to extract total RNA following the standard protocol provided by the manufacturer including an extra DNase I digestion step. After binding of the RNA to the Mini Filter RNA, we added a $50 \mu \mathrm{L}$ DNase mix containing $30 \cup$ RNase-free DNase I (Lucigen Corporation, Middleton, USA) together with the appropriate buffer and incubated for $15 \mathrm{~min}$ at room temperature. For the polymerase chain reaction (PCR) experiment, we pooled total RNA from one individual of each age $(7,14,21$ and 28-day-old bees) per tissue (brain, MMTG, DV, DL). $400 \mathrm{ng}$ total RNA of each tissue were used for cDNA synthesis using the Biozym cDNA Synthesis Kit (Biozym, Hessisch Oldendorf, Germany). The CDNAs were then analyzed in $20 \mu \mathrm{L}$ PCR reactions $\left(1 \mu \mathrm{L} c D N A, 8.2 \mu \mathrm{L} \mathrm{H} \mathrm{H}_{2} \mathrm{O}, 10 \mu \mathrm{L} 2 \times\right.$ qPCR S'Green BlueMix (Biozym, Hessisch Oldendorf, Germany), $0.4 \mu \mathrm{L}$ of each primer $(0.2 \mu \mathrm{M}$, Table 4$)$ using the following protocol: $95^{\circ} \mathrm{C}$ for 2 min and 35 cycles at $95^{\circ} \mathrm{C}$ for $5 \mathrm{~s}$ and $30^{\circ} \mathrm{C}$ for $30 \mathrm{~s}$. Finally, $10 \mu \mathrm{L}$ for each PCR reaction was analyzed on a $1.5 \%$ agarose gel. For the qPCR experiments we used individual total RNA per tissue. Here, for each sample $70 \mathrm{ng}$ (DV) and $30 \mathrm{ng}$ (DL) RNA were used. All 
cDNA synthesis reactions were performed with the Biozym cDNA Synthesis Kit (Biozym, Hessisch Oldendorf, Germany). PCR triplicates of each CDNA $(5 \mu \mathrm{L})$ were analyzed in a qPCR on a RotorGene Q (Qiagen, Hilden, Germany) in a total reaction volume of $20 \mu \mathrm{L}$. Every reaction contains $4.2 \mu \mathrm{L} \mathrm{H} \mathrm{H}_{2} \mathrm{O}, 10 \mu \mathrm{L} 2 \times$ qPCR S'Green BlueMix (Biozym, Hessisch Oldendorf, Germany), $0.4 \mu \mathrm{L}$ of each primer $(0.2 \mu \mathrm{M}$, Table 4$)$ and $5 \mu \mathrm{L}$ cDNA. Finally, octopamine receptor gene expression was determined relative to the reference genes AmGAPDH and AmRPL10 using the R package 'EasypcR' (v1.1.3) which uses the algorithm published by Hellemans et al. (2007).

\section{Pharmacological thermography}

For the reserpine experiments, forager bees and nurse bees were collected as described above. The bees were kept and fed in equal proportions in two adjacent cages $\left(34{ }^{\circ} \mathrm{C}, \mathrm{RH}=65 \%\right)$ for 3 days. The reserpine group was fed with $500 \mu \mathrm{M}$ reserpine solution (in $30 \%$ sucrose solution) ad libitum and the control group with $30 \%$ sucrose only. To enhance the solubility, the reserpine was pre-dissolved in acetone. For the experiments with receptor antagonists, the day before each measuring day, 20 bees were collected from the same hive and kept overnight in a cage at $34{ }^{\circ} \mathrm{C}(\mathrm{RH}=65 \%)$. In the incubator, the bees were fed ad libitum with $30 \%$ sucrose solution. All injection solutions were freshly prepared every experimental day. All biogenic amines and receptor antagonists were purchased from Sigma-Aldrich and were used in a concentration of $0.01 \mathrm{M}$ in saline solution ( $270 \mathrm{mM}$ sodium chloride, $3.2 \mathrm{mM}$ potassium chloride, $1.2 \mathrm{mM}$ calcium chloride, $10 \mathrm{mM}$ magnesium chloride, $10 \mathrm{mM}$ 3-( $\mathrm{N}$-morpholino)propanesulfonic acid, $\mathrm{pH}=7.4$; Erber and Kloppenburg, 1995). For solubility reasons, a 10:1 volume mixture of saline solution and dimethyl sulfoxide was used for carvedilol instead of pure buffer. Each bee was immobilized on ice until no more movement could be detected. The thorax was then punctured centrally to inject $1.0 \mu \mathrm{L}$ testing solution using a $10.0 \mu \mathrm{L}$ Hamilton syringe. Directly before the start of every measurement, the control group received an injection of the pure saline solution and the treatment group an injection of $0.01 \mathrm{M}$ of the biogenic amine or the respective antagonist directly into their flight muscles. To enable optimal conditions for thermogenesis and thermographic recordings, we adapted the method of a tethered animal that walks upon a treadmill (Moore et al., 2014). This allows the bee to seemingly move freely, while at the same time the camera always monitors the same area of the bees thorax. This setup was located inside an incubator $\left(18.5^{\circ} \mathrm{C}, \mathrm{RH}=65 \%\right)$ together with a thermographic camera (FLIR A65 camera, lens: $45^{\circ}, f=13 \mathrm{~mm}$, FLIR, Wilsonville, USA). A thermal imaging video with $30 \mathrm{frames} / \mathrm{min}$ was recorded of each bee over $10 \mathrm{~min}$. We converted the thermographic videos using the R package Thermimage (4.1.2, Tattersall, 2020) to subsequently read out the thoracic temperatures with ImageJ (1.53c, Schindelin et al., 2012).

\section{Statistical analysis}

All statistical analyses were performed using R (4.0.4 including 'stats', R Core Team, 2020) and the R packages 'rstatix' (0.7.0, Kassambara, 2020b) and 'FSA' (0.9.1, Ogle et al., 2021). We performed a Shapiro-Wilk test to check the data for normality distribution. Since most data subsets did not display a normal distribution, we analyzed the data using either the Mann-Whitney $U$ test or the Kruskal-Wallis test followed by Dunns post hoc analysis if significant differences were observable. For the statistical analysis of the pharmacological thermography experiments, we calculated the mean value per min for $T_{T H X}$ and $T_{A}$, respectively. Afterwards, the $\Delta$ temperature $\left(T_{T H X}-T_{A}\right)$ for the total time span of the experiment ( 5 or $10 \mathrm{~min}$ ) was subjected to nonparametric analysis of longitudinal data using a F1 LD F1 model of the R package 'nparLD' (2.1 Noguchi et al., 2012). Visualization of the data was performed with the R packages 'ggplot2' (3.3.3, Wickham, 2016), 'ggpubr' (0.4.0, Kassambara, 2020a), 'png' (0.1-7, Urbanek, 2013), 'cowplot' (1.1.1, Wilke, 2019), and 'magick' (2.7.0, Wilke, 2019). 
412

413

414

415

416

417

418

419

420

421

422

423

424

425

426

427

428

429

430

431

432

433

434

435

436

437

438

439

440

441

442

443

444

445

446

447

448

\section{Acknowledgments}

We thank Dirk Ahrens for beekeeping; Annette Garbe, Karin Möller, Feriba Ghanbari, Anna Senker and Linnéa Jürgensen for technical assistance during the experiments; Flavio Roces, Johannes Spaethe, Petra Högger, Ricarda Scheiner and Robin Grob for supplying technical equipment. A special thanks goes to Christian Wegener, Jens Schlossmann, Anna Stöckl and Basil el Jundi for fruitful discussions and/or reviewing earlier versions of the manuscript.

\section{Additional information}

\section{Funding}

\begin{tabular}{lll} 
Funder & Grant reference number & Author \\
\hline $\begin{array}{l}\text { Deutsche } \\
\text { Forschungsgemeinschaft }\end{array}$ & TH2264/2-1 & Markus Thamm \\
\hline $\begin{array}{l}\text { The funders had no role in study design, data collection and interpretation, } \\
\text { or the decision to submit the work for publication. }\end{array}$ \\
\hline
\end{tabular}

\section{Author contributions}

Sinan Kaya-Zeeb: Conceptualization, Formal analysis, Investigation, Visualization, Methodology, Writing - original draft, Project administration, Writing (original draft, review and editing); Lorenz Engelmayer: Investigation, Writing (review and editing); Jasmin Bayer: Investigation, Methodology, Writing (review and editing); Heike Bähre: Investigation, Resources, Methodology, Writing (review and editing); Roland Seifert: Resources, Methodology, Writing (review and editing); Oliver ScherfClavel: Resources, Methodology, Writing (review and editing); Markus Thamm: Conceptualization, Resources, Supervision, Funding acquisition, Project administration, Writing (original draft, review and editing)

\section{Author ORCIDs}

- Sinan Kaya-Zeeb orcid.org/0000-0001-5349-8787

- Oliver Scherf-Clavel orcid.org/0000-0002-1967-9231

- Markus Thamm orcid.org/0000-0003-0480-2206

\section{References}

Ablad B, Ervik M, Hallgren J, Johnsson G, Sölvell L. Pharmacological effects and serum levels of orally administered alprenolol in man. Eur J Clin Pharmacol. 1972 oct; 5(1):44-52. doi: 10.1007/bf00560895.

Ablad B, Carlsson E, Ek L. Pharmacological studies of two new cardioselective adrenergic beta-receptor antagonists. Life Sci. 1973 feb; 12(3):107-119. doi: 10.1016/0024-3205(73)90368-8.

Baines RA, Tyrer NM, Downer RGH. Serotoninergic innervation of the locust mandiblar closer muscle modulates contractions through the elevation of cyclic adenosine monophosphate. The Journal of Comparative Neurology. 1990 apr; 294(4):623-632. doi: 10.1002/cne.902940409.

Balfanz S, Jordan N, Langenstück T, Breuer J, Bergmeier V, Baumann A. Molecular, pharmacological, and signaling properties of octopamine receptors from honeybee (Apis mellifera) brain. J Neurochem. 2013; 129(2):284-296. doi: 10.1111/jnc.12619.

Baracchi D, Cusseau G, Pradella D, Turillazzi S. Defence reactions of Apis mellifera ligustica against attacks from the European hornet Vespa crabro. Ethol Ecol Evol. 2010; 22(3):281-294.

Bartrons R, Simon-Molas H, Rodríguez-García A, Castaño E, Navarro-Sabaté À, Manzano A, MartinezOutschoorn UE. Fructose 2,6-Bisphosphate in Cancer Cell Metabolism. Front Oncol. 2018 sep; 8. doi: 10.3389/fonc.2018.00331. 
Belzunces R L P Vandame, Gu X. Modulation of honey bee thermoregulation by adrenergic compounds. NeuroReport. 1996; (7):1601-1604.

Benfield P, Clissold SP, Brogden RN. Metoprolol. Drugs. 1986 may; 31(5):376-429. doi: 10.2165/00003495198631050-00002.

Beste KY, Burhenne $H$, Kaever V, Stasch JP, Seifert R. Nucleotidyl cyclase activity of soluble guanylyl cyclase $\alpha 1 \beta 1$. Biochemistry. 2012; 51(1):194-204.

Bischof LJ, Enan EE. Cloning, expression and functional analysis of an octopamine receptor from Periplaneta americana. Insect Biochem Mol Biol. 2004; 34(6):511-521.

Blau C, Wegener G. Metabolic integration in locust flight: the effect of octopamine on fructose 2, 6bisphosphate content of flight muscle in vivo. J Comp Physiol B. 1994; 164(1):11-15.

Blau C, Wegener G, Candy DJ. The effect of octopamine on the glycolytic activator fructose 2, 6-bisphosphate in perfused locust flight muscle. Insect Biochem Mol Biol. 1994; 24(7):677-683.

Blenau W, Balfanz S, Baumann A. Amtyr1: characterization of a gene from honeybee (Apis mellifera) brain encoding a functional tyramine receptor. J Neurochem. 2000; 74(3):900-908.

Blenau W, Wilms JA, Balfanz S, Baumann A. AmOcta2R: Functional Characterization of a Honeybee Octopamine Receptor Inhibiting Adenylyl Cyclase Activity. Int J Mol Sci. 2020; 21(24):9334. doi: 10.3390/ijms21249334.

Bräunig P, Pflüger HJ. The unpaired median neurons of insects. In: Advances in Insect Physiology, vol. 28 Academic Press; 2001.p. 185-IN2. doi: https://doi.org/10.1016/S0065-2806(01)28011-4.

Buchberger AK, Brettschneider D, Berg K, Jungmann D, Oehlmann J, Scheurer M, Oetken M. Effects of metoprolol on aquatic invertebrates in artificial indoor streams. J Environ Sci Health. 2018 mar; 53(8):728739. doi: 10.1080/10934529.2018.1444964.

Bujok B, Kleinhenz M, Fuchs S, Tautz J. Hot spots in the bee hive. Naturwissenschaften. 2002; 89(7):299-301.

Campbell J, Kessler B, Mayack C, Naug D. Behavioural fever in infected honeybees: parasitic manipulation or coincidental benefit? Parasitology. 2010; 137(10):1487-1491.

Chen YL, Hung YS, Yang EC. Biogenic amine levels change in the brains of stressed honeybees. Arch Insect Biochem Physiol. 2008; 68(4):241-250. doi: 10.1002/arch.20259.

Cheung M, Parmar M. Reserpine. StatPearls Publishing, Treasure Island (FL); 2020. http://europepmc.org/ books/NBK557767.

Clark MG, Bloxham DP, Holland PC, Lardy HA. Estimation of the fructose diphosphatase-phosphofructokinase substrate cycle in the flight muscle of Bombus affinis. Biochem J. 1973; 134(2):589-597.

Cook CN, Brent CS, Breed MD. Octopamine and tyramine modulate the thermoregulatory fanning response in honey bees (Apis mellifera). J Exp Biol. 2017; 220(10):1925-1930. doi: 10.1242/jeb.149203.

Correa-Fernandez F, Cruz-Landim C. Differential flight muscle development in workers, queens and males of the eusocial bees, Apis mellifera and Scaptotrigona postica. Journal of Insect Science. 2010; 10(1).

Cossío-Bayúgar R, Miranda-Miranda E, Padilla VN, Olvera-Valencia F, Reynaud E. Perturbation of tyraminergic/octopaminergic function inhibits oviposition in the cattle tick Rhipicephalus (Boophilus) microplus. J Insect Physiol. 2012 may; 58(5):628-633. doi: 10.1016/j.jinsphys.2012.01.006.

Duch C, Mentel T, Pflüger H. Distribution and activation of different types of octopaminergic DUM neurons in the locust. J Comp Neurol. 1999; 403(1):119-134.

Dzialowski EM, Turner PK, Brooks BW. Physiological and Reproductive Effects of Beta Adrenergic Receptor Antagonists in Daphnia magna. Arch Environ Contam Toxicol. 2006; 50(4):503-510. doi: 10.1007/s00244005-0121-9.

Enan EE. Molecular and pharmacological analysis of an octopamine receptor from american cockroach and fruit fly in response to plant essential oils. Arch Insect Biochem Physiol. 2005; 59(3):161-171. doi: https://doi.org/10.1002/arch.20076.

Erber J, Kloppenburg P. The modulatory effects of serotonin and octopamine in the visual system of the honeybee (Apis mellifera L.). J Comp Physiol A. 1995; . 
Esch H. Ein neuer Bewegungstyp im Schwänzeltanz der Bienen. Naturwissenschaften. 1961; 48(5):140-141.

Esch H. Body temperature and flight performance of honey bees in a servo-mechanically controlled wind tunnel. J Comp Physiol. 1976; 109(3):265-277.

Esch H, Goller F. Neural control of fibrillar muscles in bees during shivering and flight. J Exp Biol. 1991; 159(1):419-431.

Esch H, Nachtigall W, Kogge SN. Correlations between aerodynamic output, electrical activity in the indirect flight muscles and wing positions of bees flying in a servomechanically controlled wind tunnel. J Comp Physiol. 1975; 100(2):147-159.

Fic E, Kedracka-Krok S, Jankowska U, Pirog A, Dziedzicka-Wasylewska M. Comparison of protein precipitation methods for various rat brain structures prior to proteomic analysis. Electrophoresis. 2010; 31(21):35733579. doi: 10.1002/elps.201000197.

Fothergill-Gilmore LA, Michels PAM. Evolution of glycolysis. Prog Biophys Mol Biol. 1993; 59(2):105-235. doi: 10.1016/0079-6107(93)90001-z.

Fuchs S, Rende E, Crisanti A, Nolan T. Disruption of aminergic signalling reveals novel compounds with distinct inhibitory effects on mosquito reproduction, locomotor function and survival. Sci Rep. 2014; 4(1). doi: 10.1038/srep05526.

Fussnecker BL, Smith BH, Mustard JA. Octopamine and tyramine influence the behavioral profile of locomotor activity in the honey bee (Apis mellifera). J Insect Physiol. 2006; 52(10):1083-1092.

Grohmann L, Blenau W, Erber J, Ebert PR, Strünker T, Baumann A. Molecular and functional characterization of an octopamine receptor from honeybee (Apis mellifera) brain. J Neurochem. 2003; 86(3):725-735.

Hansson L, Himmelmann A. Carvedilol in the Treatment of Hypertension - A Review of the Clinical Data Base. Scand Cardiovasc J. 1998; 32(47):67-80. doi: 10.1080/140174398428072.

Harrison J. Roles of individual honeybee workers and drones in colonial thermogenesis. J Exp Biol. 1987; 129(1):53-61.

Hasan A, Danker KY, Wolter S, Bähre H, Kaever V, Seifert R. Soluble adenylyl cyclase accounts for high basal CCMP and cUMP concentrations in HEK293 and B103 cells. Biochem Biophys Res Commun. 2014; 448(2):236240.

Hazelhoff E. Ventilation in a bee-hive during summer. Physiol comp. 1954; 3:343-364.

Hellemans J, Mortier G, Paepe AD, Speleman F, Vandesompele J. qBase relative quantification framework and software for management and automated analysis of real-time quantitative PCR data. Genome Biol. 2007; 8(2):R19. doi: 10.1186/gb-2007-8-2-r19.

Hess WR. Die Temperaturregulierung im Bienenvolk. Z Vgl Physiol. 1926; 4(4):465-487.

Himmer A. Die Temperaturverhältnisse bei den sozialen Hymenopteren. Biol Rev. 1932; 7(3):224-253.

Hochman S. Metabolic recruitment of spinal locomotion: intracellular neuromodulation by trace amines and their receptors. Neural Regener Res. 2015; 10(12):1940. doi: 10.4103/1673-5374.169625.

Huang J, Hamasaki T, Ozoe Y. Pharmacological characterization of a Bombyx mori $\alpha$-adrenergic-like octopamine receptor stably expressed in a mammalian cell line. Arch Insect Biochem Physiol. 2010; 73(2):74-86.

Hue L, Rider MH. Role of fructose 2,6-bisphosphate in the control of glycolysis in mammalian tissues. Biochem J. 1987 jul; 245(2):313-324. doi: 10.1042/bj2450313.

Inkscape Developer Team. Inkscape; 2021, https://inkscape.org/, inkscape.

Jungmann D, Berg K, Dieterich A, Frank M, Gräf T, Scheurer M, Schwarz S, Siewert C, Oetken M. Health effects of metoprolol in epibenthic and endobenthic invertebrates-A basis to validate future in vitro biotests for effectbased biomonitoring. J Environ Sci Health A. 2016 nov; 52(3):189-200. doi: 10.1080/10934529.2016.1246930.

Kammer A, Heinrich B. Insect Flight Metabolism. In: Treherne JE, Berridge MJ, Wigglesworth VB, editors. Advances in Insect Physiology, vol. 13 Academic Press; 1978.p. 133-228. doi: 10.1016/S0065-2806(08)60266-0. 
541 Kassambara A. ggpubr: 'ggplot2' Based Publication Ready Plots; 2020, https://CRAN.R-project.org/package= $\mathbf{5 4 2}$ ggpubr, $r$ package version 0.4.0.

543 Kassambara A. rstatix: Pipe-Friendly Framework for Basic Statistical Tests; 2020, https://CRAN.R-project.org/ $544 \quad$ package $=$ rstatix, $r$ package version 0.6.0.

545 Ken T, Hepburn H, Radloff S, Yusheng Y, Yiqiu L, Danyin Z, Neumann P. Heat-balling wasps by honeybees. $546 \quad$ Naturwissenschaften. 2005; 92(10):492-495.

547 Kim YS, Sainz RD, Molenaar P, Summers RJ. Characterization of $\beta 1$-and $\beta 2$-adrenoceptors in rat skeletal muscles. 548 Biochem Pharmacol. 1991; 42(9):1783-1789.

Kovac H, Stabentheiner A, Brodschneider R. Contribution of honeybee drones of different age to colonial thermoregulation. Apidologie. 2009; 40(1):82-95. doi: 10.1051/apido/2008069.

551

552

553

554

555

556

Lange AB, Nykamp DA. Signal transduction pathways regulating the contraction of an insect visceral muscle. Archives of Insect Biochemistry and Physiology. 1996; 33(3-4):183-196. doi: 10.1002/(sici)15206327(1996)33:3/4<183::aid-arch2>3.0.c0;2-u.

Liggett SB, Shah SD, Cryer PE. Characterization of beta-adrenergic receptors of human skeletal muscle obtained by needle biopsy. Am J Physiol - Endocrinol Metab. 1988; 254(6):E795-E798.

MarkI H. Peripheres Nervensystem und Muskulatur im Thorax von der Arbeiterin von Apis mellifera L. Formica polyctena. 1966; p. 483-496.

Moore RJD, Taylor GJ, Paulk AC, Pearson T, van Swinderen B, Srinivasan MV. FicTrac: A visual method for tracking spherical motion and generating fictive animal paths. J Neurosci Meth. 2014; 225:106-119. doi: 10.1016/j.jneumeth.2014.01.010.

Müller U. Prolonged activation of cAMP-dependent protein kinase during conditioning induces long-term memory in honeybees. Neuron. 2000; 27(1):159-168.

Narabayashi H, Lawson J, Uyeda K. Regulation of phosphofructokinase in perfused rat heart. Requirement for fructose 2, 6-bisphosphate and a covalent modification. J Biol Chem. 1985; 260(17):9750-9758.

Newsholme E, Crabtree B. The role of fructose-1, 6-diphosphatase in the regulation of glycolysis in skeletal muscle. FEBS lett. 1970; 7(2):195-198.

Newsholme E, Crabtree B. Substrate cycles in metabolic regulation and in heat generation. In: Biochem. Soc. Symp. No. 41; 1976. p. 61-109.

Newsholme E, Crabtree B, Higgins S, Thornton S, Start C. The activities of fructose diphosphatase in flight muscles from the bumble-bee and role of this enzyme in heat generation. Biochem J. 1972; 128(1):89-97.

Noguchi K, Gel YR, Brunner E, Konietschke F. nparLD: An R Software Package for the Nonparametric Analysis of Longitudinal Data in Factorial Experiments. J Stat Softw. 2012; 50(12):1-23. http://www.jstatsoft.org/v50/i12/.

Ogle DH, Doll JC, Wheeler P, Dinno A. FSA: Fisheries Stock Analysis; 2021, https://github.com/droglenc/FSA, r package version 0.9.1.

Ohta H, Utsumi T, Ozoe Y. B96Bom encodes a Bombyx mori tyramine receptor negatively coupled to adenylate cyclase. Insect Mol Biol. 2003; 12(3):217-223.

Ohtani A, Arai Y, Ozoe F, Ohta H, Narusuye K, Huang J, Enomoto K, Kataoka H, Hirota A, Ozoe Y. Molecular cloning and heterologous expression of an $\alpha$-adrenergic-like octopamine receptor from the silkworm Bombyx mori. Insect Mol Biol. 2006; 15(6):763-772. doi: 10.1111/j.1365-2583.2006.00676.x.

Pan KC. The neural organization of the ocellar system andassociated pathways in the central nervous system of the workerhoneybee. PhD thesis, University of London; 1980.

Pauls D, Blechschmidt C, Frantzmann F, el Jundi B, Selcho M. A comprehensive anatomical map of the peripheral octopaminergic/tyraminergic system of Drosophila melanogaster. Sci Rep. 2018; 8(1). doi: 10.1038/s41598-018-33686-3.

Plummer AJ, Earl A, Schneider J, Trapold J, Barrett W. Pharmacology of Rauwolfia alkaloids, including reserpine. Ann N Y Acad Sci. 1954; 59(1):8-21. 
Qi Yx, Xu G, Gu Gx, Mao F, Ye Gy, Liu W, Huang J. A new Drosophila octopamine receptor responds to serotonin. Insect Biochem Mol Biol. 2017 nov; 90:61-70. doi: 10.1016/j.ibmb.2017.09.010.

R Core Team. R: A Language and Environment for Statistical Computing. R Foundation for Statistical Computing, Vienna, Austria; 2020, https://www.R-project.org/.

Reim T, Balfanz S, Baumann A, Blenau W, Thamm M, Scheiner R. AmTAR2: Functional characterization of a honeybee tyramine receptor stimulating adenylyl cyclase activity. Insect Biochem Mol Biol. 2017; 80:91 100. doi: 10.1016/j.ibmb.2016.12.004.

Rider MH, Bertrand L, Vertommen D, Michels PA, Rousseau GG, Hue L. 6-phosphofructo-2-kinase/fructose2, 6-bisphosphatase: head-to-head with a bifunctional enzyme that controls glycolysis. Biochem J. 2004; 381(3):561-579.

Roberts SP, Elekonich MM. Muscle biochemistry and the ontogeny of flight capacity during behavioral development in the honey bee, Apis mellifera. J Exp Biol. 2005; 208(22):4193-4198.

Roeder T. Tyramine and octopamine: ruling behavior and metabolism. Annu Rev Entomol. 2005; 50:447-477.

Roeder T. The control of metabolic traits by octopamine and tyramine in invertebrates. J Exp Biol. 2020; 223(7).

Schindelin J, Arganda-Carreras I, Frise E, Kaynig V, Longair M, Pietzsch T, Preibisch S, Rueden C, Saalfeld S, Schmid B, et al. Fiji: an open-source platform for biological-image analysis. Nature methods. 2012; 9(7):676682.

Schlurmann M, Hausen K. Mesothoracic ventral unpaired median (mesVUM) neurons in the blowfly Calliphora erythrocephala. J Comp Neurol. 2003; 467(3):435-453.

Seeley TD. The wisdom of the hive. Harvard University Press, Cambridge Mass, London; 1995.

Simpson J. Nest climate regulation in honey bee colonies. Science. 1961; 133(3461):1327-1333.

Spindler SR, Mote PL, Li R, Dhahbi JM, Yamakawa A, Flegal JM, Jeske DR, Li R, Lublin AL. $\beta 1$-Adrenergic receptor blockade extends the life span of Drosophila and long-lived mice. AGE. 2013; 35(6):2099-2109. doi: 10.1007/s11357-012-9498-3.

Stabentheiner A, Kovac H, Brodschneider R. Honeybee Colony Thermoregulation - Regulatory Mechanisms and Contribution of Individuals in Dependence on Age, Location and Thermal Stress. PLoS ONE. 2010; 5(1):e8967. doi: 10.1371/journal.pone.0008967.

Stabentheiner A, Pressl H, Papst T, Hrassnigg N, Crailsheim K. Endothermic heat production in honeybee winter clusters. J Exp Biol. 2003; 206(2):353-358.

Staples JF, Koen EL, Laverty TM. Futile cycle'enzymes in the flight muscles of North American bumblebees. J Exp Biol. 2004; 207(5):749-754.

Starks PT, Blackie CA, Seeley TD. Fever in honeybee colonies. Naturwissenschaften. 2000; 87(5):229-231.

Sujkowski A, Gretzinger A, Soave N, Todi SV, Wessells R. Alpha- and beta-adrenergic octopamine receptors in muscle and heart are required for Drosophila exercise adaptations. PLOS Genetics. 2020; 16(6):e1008778. doi: 10.1371/journal.pgen.1008778.

Sujkowski A, Ramesh D, Brockmann A, Wessells R. Octopamine Drives Endurance Exercise Adaptations in Drosophila. Cell Rep. 2017; 21(7):1809-1823. doi: 10.1016/j.celrep.2017.10.065.

Tattersall G, gtatters/Thermimage: Thermimage v4.1.2. Zenodo; 2020. https://doi.org/10.5281/zenodo.3992849, doi: 10.5281/zenodo.3992849.

Tautz J, Maier S, Groh C, Rössler W, Brockmann A. Behavioral performance in adult honey bees is influenced by the temperature experienced during their pupal development. Proc Natl Acad Sci U S A. 2003; 100:73437347.

Urbanek S. png: Read and write PNG images; 2013, https://CRAN.R-project.org/package=png, r package version 0.1-7.

Wallberg A, Han F, Wellhagen G, Dahle B, Kawata M, Haddad N, Simões ZLP, Allsopp MH, Kandemir I, De la Rúa $P$, et al. A worldwide survey of genome sequence variation provides insight into the evolutionary history of the honeybee Apis mellifera. Nature genetics. 2014; 46(10):1081-1088. 
634 Wallberg A, Schöning C, Webster MT, Hasselmann M. Two extended haplotype blocks are associated with 635 adaptation to high altitude habitats in East African honey bees. PLoS Genet. 2017; 13:e1006792.

636

Wang Q, Xu X, Zhu X, Chen L, Zhou S, Huang ZY, Zhou B. Low-Temperature Stress during Capped Brood Stage 637 Increases Pupal Mortality, Misorientation and Adult Mortality in Honey Bees. PloS one. 2016; 11:e0154547.

638 Wegener G. Flying insects: model systems in exercise physiology. Experientia. 1996; 52(5):404-412.

639 Weiss K. Über die Lebensfähigkeit von offener und gedeckelter Brut ausserhalb des Bienenvolkes. Z 640 Bienenforsch. 1962; 6:104-114.

${ }_{641}$ Wenner AM. Sound production during the waggle dance of the honey bee. Anim Behav. 1962; 10(1-2):79-95.

642 Wickham H. ggplot2: Elegant Graphics for Data Analysis. Springer-Verlag New York; 2016. https://ggplot2. 643 tidyverse.org.

644 Wilke CO. cowplot: Streamlined Plot Theme and Plot Annotations for 'ggplot2'; 2019, https://CRAN.R-project. $645 \quad$ org $/$ package $=$ cowplot, $r$ package version 1.0.0.

646 Zhang XC, Feng W. Thermodynamic aspects of ATP hydrolysis of actomyosin complex. Biophys Rep. 2016; $647 \quad 2(5-6): 87-94$. 
bioRxiv preprint doi: https://doi.org/10.1101/2021.11.04.467276; this version posted November 6. 2021. The copyright holder for this preprint (which was not certified by peer review) is the author/funder, who has granted bioRxiv a license to display the preprint in perpetuity. It is made available under aCC-BY 4.0 International license.

Appendix 0 Table 1. Statistical analysis of HPLC analysis of the octopamine content. ns = not significant.

\begin{tabular}{|c|c|c|c|c|}
\hline analysis & test & groups $(\mathrm{n})$ & result & \\
\hline \multirow{11}{*}{$\begin{array}{l}\text { HPLC } \\
\text { octopamine } \\
\text { DV } \\
\text { Figure 1A }\end{array}$} & Kruskal-Wallis test & & $\chi^{2}=15.772, d f=4, p=0,0033$ & ** \\
\hline & \multirow{10}{*}{ Dunns test } & 0 days (6) vs. 7 days (6) & $Z=-2.4593, p_{a d j}=0.1392$ & ns \\
\hline & & 0 days (6) vs. 14 days (6) & $Z=-2.8856, p_{a d j}=0.0391$ & * \\
\hline & & 0 days (6) vs. 21 days (6) & $Z=-2.7217, p_{a d j}=0.065$ & ns \\
\hline & & 0 days (6) vs. 28 days (6) & $Z=-3.7382, p_{a d j}=0.0017$ & ** \\
\hline & & 7 days (6) vs. 14 days (6) & $\mathrm{Z}=0.4263, \mathrm{p}_{\mathrm{adj}}=1.0$ & ns \\
\hline & & 7 days (6) vs. 21 days (6) & $Z=0.2623, p_{a d j}=1.0$ & ns \\
\hline & & 7 days (6) vs. 28 days (6) & $Z=1.2789, p_{a d j}=1.0$ & ns \\
\hline & & 14 days (6) vs. 21 days (6) & $\mathrm{Z}=0.164, \mathrm{p}_{\mathrm{adj}}=1.0$ & ns \\
\hline & & 14 days (6) vs. 28 days (6) & $Z=-0.8526, p_{a d j}=1.0$ & ns \\
\hline & & 21 days (6) vs. 28 days (6) & $Z=-1.0165, p_{a d j}=1.0$ & ns \\
\hline \multirow{11}{*}{$\begin{array}{l}\text { HPLC } \\
\text { octopamine } \\
\text { DL } \\
\text { Figure 1B }\end{array}$} & Kruskal-Wallis test & & $\chi^{2}=16.292, d f=4, p=0.0027$ & ** \\
\hline & \multirow{10}{*}{ Dunns test } & 0 days (6) vs. 7 days (6) & $Z=-1.3117, p_{a d j}=1.0$ & ns \\
\hline & & 0 days (6) vs. 14 days (6) & $Z=-2.6561, p_{a d j}=0.0791$ & * \\
\hline & & 0 days (6) vs. 21 days (6) & $Z=-1.9019, p_{a d j}=0.5718$ & ns \\
\hline & & 0 days (6) vs. 28 days (6) & $Z=-3.8038, p_{a d j}=0.0014$ & ** \\
\hline & & 7 days (6) vs. 14 days (6) & $\mathrm{Z}=1.3444, \mathrm{p}_{\mathrm{adj}}=1.0$ & ns \\
\hline & & 7 days (6) vs. 21 days (6) & $Z=0.5902, p_{a d j}=1.0$ & ns \\
\hline & & 7 days (6) vs. 28 days (6) & $\mathrm{Z}=2.4921, \mathrm{p}_{\mathrm{adj}}=0.127$ & ns \\
\hline & & 14 days (6) vs. 21 days (6) & $Z=0.7542, p_{a d j}=1.0$ & ns \\
\hline & & 14 days (6) vs. 28 days (6) & $Z=-1.1477, p_{a d j}=1.0$ & ns \\
\hline & & 21 days (6) vs. 28 days (6) & $Z=-1.9019, p_{a d j}=0.5718$ & ns \\
\hline $\begin{array}{l}\text { HPLC } \\
\text { octopamine }\end{array}$ & \multicolumn{2}{|l|}{ Kruskal-Wallis test } & $\chi^{2}=5.4912, \mathrm{df}=4, \mathrm{p}=0.2405$ & ns \\
\hline $\begin{array}{l}\text { MMTG } \\
\text { Figure 1C }\end{array}$ & \multicolumn{4}{|c|}{ groups (n): 0 days (7), 7 days (8), 14 days (7), 21 days (8), 28 days (8) } \\
\hline
\end{tabular}


bioRxiv preprint doi: https://doi.org/10.1101/2021.11.04.467276; this version posted November $6,2021$. The copyright holder for this preprint (which was not certified by peer review) is the author/funder, who has granted bioRxiv a license to display the preprint in perpetuity. It is made available under aCC-BY 4.0 International license.

Appendix 0 Table 2. Statistical analysis of the flight muscle gene expression analysis. ns = not significant.

\begin{tabular}{|c|c|c|c|c|}
\hline analysis & test & groups $(n)$ & result & \\
\hline \multirow{11}{*}{$\begin{array}{l}\text { qPCR } \\
\text { AmOARa1 } \\
\text { DV } \\
\text { Figure 3D }\end{array}$} & Kruskal-Wallis test & & $\chi^{2}=25.734, d f=4, p=0.00004$ & $\star \star \star$ \\
\hline & \multirow{10}{*}{ Dunns test } & 0 days (8) vs. 7 days (8) & $Z=-1.6253, p_{a d j}=1.0$ & ns \\
\hline & & 0 days (8) vs. 14 days (8) & $Z=-3.9776, p_{a d j}=0.0007$ & $\star \star * *$ \\
\hline & & 0 days ( 8 ) vs. 21 days ( 8 ) & $Z=-3.9135, p_{a d j}=0.0009$ & $\star \star *$ \\
\hline & & 0 days ( 8 ) vs. 28 days ( 8 ) & $Z=-3.8493, p_{a d j}=0.0012$ & ** \\
\hline & & 7 days (8) vs. 14 days ( 8 ) & $Z=-2.3523, p_{a d j}=0.1866$ & ns \\
\hline & & 7 days (8) vs. 21 days ( 8 ) & $Z=-2.2882, p_{a d j}=0.2213$ & ns \\
\hline & & 7 days (8) vs. 28 days (8) & $Z=-2.224, p_{a d j}=0.2615$ & ns \\
\hline & & 14 days (8) vs. 21 days (8) & $Z=0.0642, p_{a d j}=1.0$ & ns \\
\hline & & 14 days (8) vs. 28 days (8) & $Z=0.1283, p_{a d j}=1.0$ & ns \\
\hline & & 21 days (8) vs. 28 days (8) & $\mathrm{Z}=0.0642, \mathrm{p}_{\mathrm{adj}}=1.0$ & ns \\
\hline \multirow{11}{*}{$\begin{array}{l}\text { qPCR } \\
\text { AmOARa1 } \\
\text { DL } \\
\text { Figure 3C }\end{array}$} & Kruskal-Wallis test & & $\chi^{2}=28.163, d f=4, p=0.00001$ & $\star \star \star *$ \\
\hline & \multirow{10}{*}{ Dunns test } & 0 days (8) vs. 7 days (8) & $Z=-1.5661, p_{a d j}=1.0$ & ns \\
\hline & & 0 days (8) vs. 14 days (8) & $Z=-4.4373, p_{a d j}=0.0001$ & $\star \star *$ \\
\hline & & 0 days (8) vs. 21 days (7) & $Z=-3.6548, p_{a d j}=0.0026$ & ** \\
\hline & & 0 days ( 8 ) vs. 28 days (5) & $Z=-3.7128, p_{a d j}=0.002$ & ** \\
\hline & & 7 days (8) vs. 14 days (8) & $Z=-2.8712, p_{a d j}=0.0409$ & * \\
\hline & & 7 days (8) vs. 21 days (7) & $Z=-2.1418, p_{a d j}=0.322$ & ns \\
\hline & & 7 days (8) vs. 28 days (5) & $\mathrm{Z}=-2.3392, \mathrm{p}_{\mathrm{adj}}=0193$ & ns \\
\hline & & 14 days (8) vs. 21 days (7) & $Z=0.6320, p_{a d j}=1.0$ & ns \\
\hline & & 14 days (8) vs. 28 days (5) & $Z=0.179, p_{a d j}=1.0$ & ns \\
\hline & & 21 days (7) vs. 28 days (5) & $Z=-0.3844, p_{a d j}=1.0$ & ns \\
\hline \multirow{11}{*}{$\begin{array}{l}\text { qPCR } \\
\text { AmOARß2 } \\
\text { DV } \\
\text { Figure 3D }\end{array}$} & Kruskal-Wallis test & & $\chi^{2}=24.54, \mathrm{df}=4, \mathrm{p}=0.00006$ & 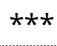 \\
\hline & \multirow{10}{*}{ Dunns test } & 0 days (8) vs. 7 days (8) & $Z=-1.6894, p_{a d j}=0,911$ & ns \\
\hline & & 0 days (8) vs. 14 days (8) & $Z=-2.8228, p_{a d j}=0.0476$ & * \\
\hline & & 0 days (8) vs. 21 days (8) & $\mathrm{Z}=-3.8707, \mathrm{p}_{\mathrm{adj}}=0.0011$ & ** \\
\hline & & 0 days ( 8 ) vs. 28 days ( 8 ) & $Z=-4.3412, p_{a d j}=0.0001$ & $\star * *$ \\
\hline & & 7 days (8) vs. 14 days (8) & $\mathrm{Z}=-1.1334, \mathrm{p}_{\mathrm{adj}}=1.0$ & ns \\
\hline & & 7 days (8) vs. 21 days ( 8 ) & $Z=-2.1813, p_{a d j}=0.292$ & ns \\
\hline & & 7 days (8) vs. 28 days (8) & $Z=-2.6517, p_{a d j}=0.0801$ & ns \\
\hline & & 14 days (8) vs. 21 days (8) & $Z=-1.0479, p_{a d j}=1.0$ & ns \\
\hline & & 14 days (8) vs. 28 days (8) & $Z=-1.5183, p_{a d j}=1.0$ & ns \\
\hline & & 21 days (8) vs. 28 days (8) & $Z=-0.4705, p_{a d j}=1.0$ & ns \\
\hline \multirow{11}{*}{$\begin{array}{l}\text { qPCR } \\
\text { AmOARß2 } \\
\text { DL } \\
\text { Figure 3E }\end{array}$} & Kruskal-Wallis test & & $\chi^{2}=24.737, d f=4, p=0.00006$ & $\star \star *$ \\
\hline & \multirow{10}{*}{ Dunns test } & 0 days (8) vs. 7 days ( 8 ) & $\mathrm{Z}=0.5429, \mathrm{p}_{\mathrm{adj}}=1.0$ & ns \\
\hline & & 0 days (8) vs. 14 days (7) & $Z=-2.9652, p_{a d j}=0.0302$ & * \\
\hline & & 0 days (8) vs. 21 days (6) & $Z=-2.4814, p_{a d j}=0.130$ & ns \\
\hline & & 0 days ( 8 ) vs. 28 days (4) & $Z=-3.1454, p_{a d j}=0.0166$ & * \\
\hline & & 7 days (8) vs. 14 days (7) & $Z=-3.4897, p_{a d j}=0.0048$ & ** \\
\hline & & 7 days (8) vs. 21 days (6) & $Z=-2.9841, p_{a d j}=0.0284$ & * \\
\hline & & 7 days (8) vs. 28 days (4) & $Z=-3.5887, p_{a d j}=0.0033$ & ** \\
\hline & & 14 days (7) vs. 21 days (6) & $Z=0.3496, p_{a d j}=1.0$ & ns \\
\hline & & 14 days (7) vs. 28 days (4) & $Z=-0.6246, p_{a d j}=1.0$ & ns \\
\hline & & 21 days (6) vs. 28 days (4) & $Z=-0.9079, p_{a d j}=1.0$ & ns \\
\hline
\end{tabular}


bioRxiv preprint doi: https://doi.org/10.1101/2021.11.04.467276; this version posted November $6,2021$. The copyright holder for this preprint (which was not certified by peer review) is the author/funder, who has granted bioRxiv a license to display the preprint in perpetuity. It is made available under aCC-BY 4.0 International license.

Appendix 0 Table 3. Statistical analysis of the thermogenesis dependent on the pharmacological treatment. $\mathrm{c}=$ control, $r$ = reserpine, ATS = ANOVA type statistic, ns = not significant.

\begin{tabular}{|c|c|c|c|c|c|}
\hline experiment & groups (n) & ATS & df & $\mathbf{p}$ & \\
\hline $\begin{array}{l}\text { reserpine } \\
\text { nurse bees } \\
\text { Figure 4D }\end{array}$ & $\begin{array}{l}c+\text { ringer }(21) \text { vs. } r+\text { ringer }(23) \\
c+\text { ringer }(21) \text { vs. } r+\text { octopamine }(23) \\
r+\text { ringer }(23) \text { vs. } r+\text { octopamine }(23)\end{array}$ & $\begin{array}{l}9.3635 \\
13.9618 \\
0.0952 \\
14.2223 \\
\end{array}$ & $\begin{array}{l}1.9854 \\
1.0 \\
1.0 \\
1.0 \\
\end{array}$ & $\begin{array}{l}0.00009 \\
0.0002 \\
0.7577 \\
0.0002 \\
\end{array}$ & $\begin{array}{c}* \star \star \\
\star \star * * \\
\mathrm{nS} \\
\star \star \star \\
\end{array}$ \\
\hline $\begin{array}{l}\text { reserpine } \\
\text { forager bees } \\
\text { Figure 4D }\end{array}$ & $\begin{array}{l}\text { c + ringer (29) Vs. } r+\text { ringer }(28) \\
\text { c + ringer (29) vs. } r+\text { octopamine }(29) \\
r+\text { ringer(28) vs. } r+\text { octopamine }(29)\end{array}$ & $\begin{array}{l}14.5704 \\
126.5492 \\
0.0753 \\
21.1833 \\
\end{array}$ & $\begin{array}{l}1.9437 \\
1.0000 \\
1.0 \\
1.0000 \\
\end{array}$ & $\begin{array}{l}0.0000006 \\
0.0000003 \\
0.7838 \\
0.000004 \\
\end{array}$ & $\begin{array}{l}* \star \star \\
\star \star \star * \\
\mathrm{~ns} \\
\star \star \star \\
\end{array}$ \\
\hline $\begin{array}{l}\text { reserpine } \\
\text { cAMP } \\
\text { quantification } \\
\text { Figure 4E } \\
\end{array}$ & $\begin{array}{l}c+\text { ringer }(26) \text { Vs. } r \text { + ringer }(21) \\
c+\text { ringer }(26) \text { vs. } r+\text { octopamine }(23) \\
r+\text { ringer }(21) \text { vs. } r+\text { octopamine }(23)\end{array}$ & $\begin{array}{l}22.8759 \\
39.9913 \\
0.1155 \\
37.3015 \\
\end{array}$ & $\begin{array}{l}1.8981 \\
1.0000 \\
1.0 \\
1.0000 \\
\end{array}$ & $\begin{array}{l}0,0000000003 \\
0.0000000003 \\
0.734 \\
0.000000001\end{array}$ & 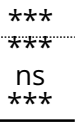 \\
\hline $\begin{array}{l}\text { mianserin } \\
\text { nurse bees } \\
\text { forager bees } \\
\text { Figure } 5 \mathrm{~A} \\
\end{array}$ & $\begin{array}{l}\text { control (30) vs. mianserin (30) } \\
\text { control (30) vs. mianserin (30) }\end{array}$ & $\begin{array}{l}9.2737 \\
8.4638\end{array}$ & $\begin{array}{l}1.0000 \\
1.0000\end{array}$ & $\begin{array}{l}0.0023 \\
0.0036\end{array}$ & $\begin{array}{ll}\star \star \\
\star \star\end{array}$ \\
\hline $\begin{array}{l}\text { yohimbine } \\
\text { nurse bees } \\
\text { forager bees } \\
\text { Figure 5B }\end{array}$ & $\begin{array}{l}\text { control (30) vs. yohimbine (30) } \\
\text { control (32) vs. yohimbine (33) }\end{array}$ & $\begin{array}{l}0.8011 \\
0.0584\end{array}$ & $\begin{array}{l}1.0000 \\
1.0000\end{array}$ & $\begin{array}{l}0.3708 \\
0.8091\end{array}$ & $\begin{array}{l}\text { ns } \\
\text { ns }\end{array}$ \\
\hline $\begin{array}{l}\text { alprenolol } \\
\text { nurse bees } \\
\text { forager bees } \\
\text { Figure 5C }\end{array}$ & $\begin{array}{l}\text { control (30) vs. alprenolol (30) } \\
\text { control (34) vs. alprenolol (33) }\end{array}$ & $\begin{array}{l}7.5516 \\
10.9721\end{array}$ & $\begin{array}{l}1.0000 \\
1.0000\end{array}$ & $\begin{array}{l}0.0059 \\
0.0009\end{array}$ & $\begin{array}{l}\star \star \\
\star \star * *\end{array}$ \\
\hline $\begin{array}{l}\text { carvedilol } \\
\text { nurse bees } \\
\text { forager bees }\end{array}$ & $\begin{array}{l}\text { control (30) vs. carvedilol (30) } \\
\text { control (36) vs. carvedilol (34) }\end{array}$ & $\begin{array}{l}0.1235 \\
0.2650\end{array}$ & $\begin{array}{l}1.0000 \\
1.0000\end{array}$ & $\begin{array}{l}0.7252 \\
0.6067\end{array}$ & $\begin{array}{ll}\text { ns } \\
\text { ns }\end{array}$ \\
\hline $\begin{array}{l}\text { metoprolol } \\
\text { nurse bees } \\
\text { forager bees }\end{array}$ & $\begin{array}{l}\text { control (30) vs. metoprolol (30) } \\
\text { control (36) vs. metoprolol (36) }\end{array}$ & $\begin{array}{l}0.1031 \\
0.2029\end{array}$ & $\begin{array}{l}1.0000 \\
1.0000\end{array}$ & $\begin{array}{l}0.7481 \\
0.6524\end{array}$ & $\begin{array}{ll}\text { ns } \\
\text { ns }\end{array}$ \\
\hline
\end{tabular}

Appendix 0 Table 4. Primers used to determine receptor gene expression. The respective gene, NCBI Gene ID, the sequence of the corresponding forward and reverse primers, and the expected length of the product are shown.

\begin{tabular}{|c|c|c|c|c|}
\hline Gene & Gene ID & Primer & Sequence & product length \\
\hline$A m G A P D H$ & 410122 & $\begin{array}{l}\text { forward } \\
\text { reverse }\end{array}$ & $\begin{array}{l}\text { 5'-CCCGAGTGAATAGATTTGCGAAGAC-3' } \\
\text { 5'-GGCAACAACCTGAGCACCG-3' }\end{array}$ & 112 bp \\
\hline AmRPL10 & 409589 & $\begin{array}{l}\text { forward } \\
\text { reverse }\end{array}$ & $\begin{array}{l}\text { 5'-CGATAAGAAACGTAAGTCAATATGGGGC-3' } \\
5^{\prime} \text {-CGTATCTTTGGATCAGGCACACC-3' }\end{array}$ & 116 bp \\
\hline AmOARa1 & 406068 & $\begin{array}{l}\text { forward } \\
\text { reverse }\end{array}$ & $\begin{array}{l}\text { 5'-GCAGGAGGAACAGCTGCGAG-3' } \\
\text { 5'-GCCGCCTTCGTCTCCATTCG-3' }\end{array}$ & 154 bp \\
\hline AmOARa2 & 726331 & $\begin{array}{l}\text { forward } \\
\text { reverse }\end{array}$ & $\begin{array}{l}\text { 5'-GCGAGCATCATGAACTTGTG-3' } \\
\text { 5'-CGTAGCCTATGTCCTCTGAAAG-3' }\end{array}$ & $223 b p$ \\
\hline$A m O A R \beta 1$ & 413698 & $\begin{array}{l}\text { forward } \\
\text { reverse }\end{array}$ & $\begin{array}{l}\text { 5'-GGAGTAAAGTAGCAGCCGCTC-3' } \\
\text { 5'-GTGATCTGTGGCTCCTCTGGT-3' }\end{array}$ & 124 bp \\
\hline$A m O A R \beta 2$ & 412896 & $\begin{array}{l}\text { forward } \\
\text { reverse }\end{array}$ & $\begin{array}{l}\text { 5'-CTCGAGCGAGGAGAAGTTGT-3' } \\
\text { 5'-CCAACGCTAAAGAGACCACG-3' }\end{array}$ & $167 b p$ \\
\hline$A m O A R \beta 3 / 4$ & 412994 & $\begin{array}{l}\text { forward } \\
\text { reverse }\end{array}$ & $\begin{array}{l}\text { 5'-CGAGGACGCTCGGAATAATA-3' } \\
\text { 5'-GAAGTCGCGGTTGAAGTACG-3' }\end{array}$ & 191 bp \\
\hline AmTAR1 & 406110 & $\begin{array}{l}\text { forward } \\
\text { reverse }\end{array}$ & $\begin{array}{l}\text { 5'-AGCCGACCGAGGTCACGATAG-3' } \\
\text { 5'-CCCATTATCACGCCCAATGTCC-3' }\end{array}$ & $169 \mathrm{bp}$ \\
\hline AmTAR2 & 410755 & $\begin{array}{l}\text { forward } \\
\text { reverse }\end{array}$ & $\begin{array}{l}\text { 5'-CAGGTGGTACCTGGGAGTTG-3' } \\
\text { 5'-CAGCTAGATACCTGTCTATGGATATGG-3' }\end{array}$ & 171 bp \\
\hline
\end{tabular}




\section{A}
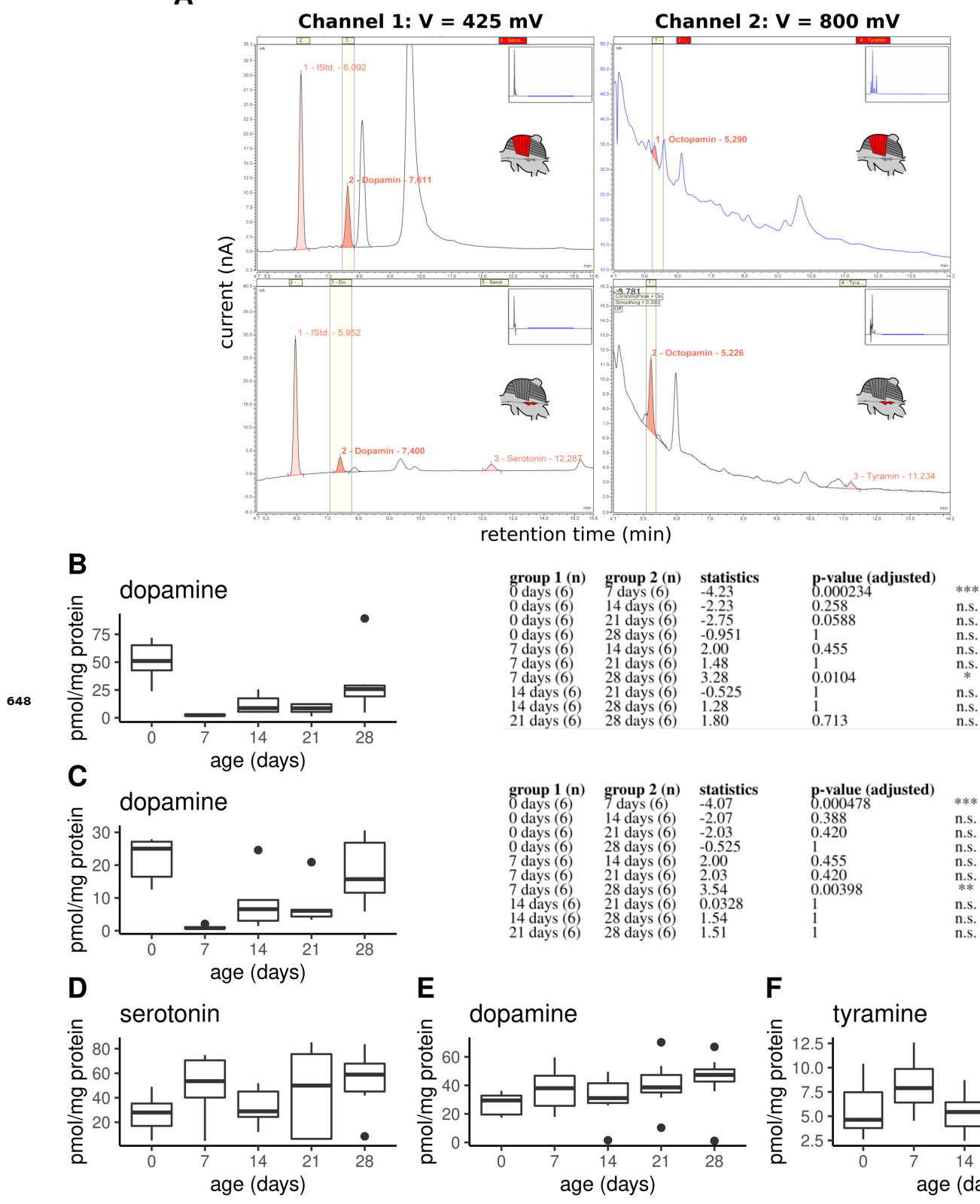

*.
n.s.
n.s.
n.s.
n.s.
n.s.
$*$
n.s.
n.s.
n.s.



*.*.
n.s.
n.s.
n.s.
n.s.
n.s.
$* *$
n.s.
n.s.
n.s.

Figure 1-Figure supplement 1. Monoamine quantification in workerbee thoracic tissues.

A) Example chromatograms of individual DV (top) and MMTG samples (bottom). B-F) Dopamine concentrations in dorsoventral (B; Kruskal-Wallis test: $\chi^{2}=21.381$, $d f=4, p=0.0003$ ) and dorsallongitudinal flight muscles $\left(C ; \chi^{2}=20.215, \mathrm{df}=4, \mathrm{p}=0.0005\right)$ are high in newly emerged bees and dramatically decrease until the age of 7 days. Afterwards, dopamine concentrations increases with aging. Group comparison results (Dunns test) are shown to the right of each graph. Additionally, serotonin ( $\left.\mathrm{D} ; \chi^{2}=6.489, \mathrm{df}=4, \mathrm{p}=0.166\right)$, dopamine $\left(\mathrm{E} ; \chi^{2}=7.4, \mathrm{df}=4, \mathrm{p}=0.116\right)$, and tyramine $\left(\mathrm{D} ; \chi^{2}=6.226, \mathrm{df}=4, \mathrm{p}=0.183\right.$ ) are detectable in the mesometa-thoracic ganglia, wheras no agerelated differences are observable. Shown is median $\pm \mathrm{IQR}$. 

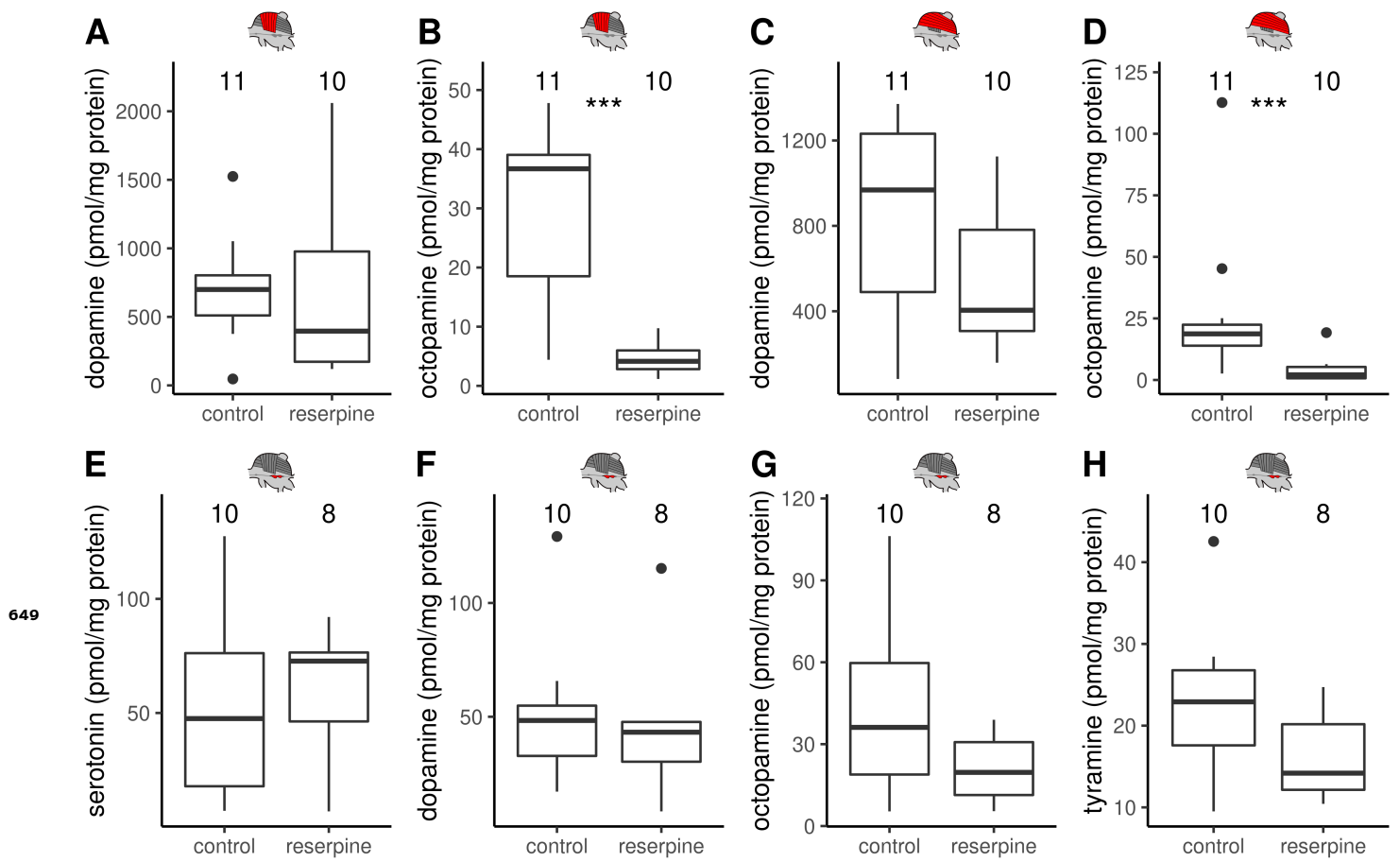

Figure 4-Figure supplement 1. The effect of reserpine on monoamine concentrations in DV, DL and MMTG. A-H) Monoamine concentrations in the thoracic tissues quantified by HPLC-ECD. Reserpinezed bees have significant lower octopamine $(B, D)$ but not dopamine concentrations $(A, C)$ than control animals in both dorsoventral (A-B) and dorsal-longitudinal flight muscles (C-D). In the mesometa-thoracic ganglia serotonin $(E)$, dopamine $(F)$, octopamine $(G)$, and tyramine $(H)$ were detectable but no reserpine effect was observable. Mann-Whitney $U$ test: DV \& octopamine, $W=$ 105, $z=-3.70, p=0.00010 ; D L \&$ octopamine: $, W=102, z=-3.37, p=0.00037$; all others: $p>0.05$. Shown is median $\pm \mathrm{IQR}$.

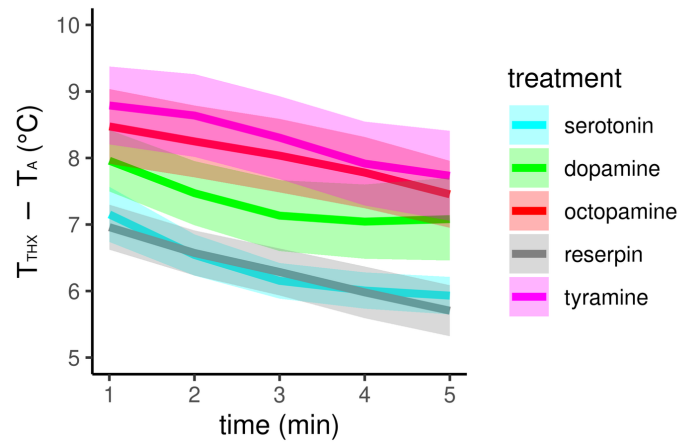

\begin{tabular}{|c|c|c|c|c|c|}
\hline & & $\begin{array}{l}\text { ATS } \\
3.413\end{array}$ & $\begin{array}{l}\text { df } \\
3.914\end{array}$ & $\begin{array}{l}\text { p-value } \\
0.0089\end{array}$ & ** \\
\hline group 1 (n) & group 2 (n) & ATS & df & p-value & \\
\hline reserpine (20) & octopamine (21) & 5.913 & 1.000000 & 0.0150 & * \\
\hline reserpine (20) & dopamine (19) & 2.4137 & 1.000000 & 0.1203 & n.s. \\
\hline reserpine (20) & tyramine $(22)$ & 7.4217 & 1.000000 & 0.0064 & $* *$ \\
\hline reserpine (20) & serotonin (21) & 0.0083 & 1.000000 & 0.9275 & n.s. \\
\hline octopamine (21) & dopamine (19) & 0.8596 & 1.000000 & 0.3539 & n.s. \\
\hline octopamine (21) & tyramine $(22)$ & 0.0452 & 1.000000 & 0.8316 & n.s. \\
\hline octopamine (21) & serotonin (21) & 6.2233 & 1.000000 & 0.0126 & $*$ \\
\hline dopamine (19) & tyramine (22) & 1.3761 & 1.000000 & 0.2408 & n.s. \\
\hline dopamine (19) & serotonin (21) & 2.4608 & 1.000000 & 0.1167 & n.s. \\
\hline tyramine $(22)$ & serotonin (21) & 7.9104 & 1.000000 & 0.0049 & $* *$ \\
\hline
\end{tabular}

Figure 4-Figure supplement 2. The effect of different monoamines on thermogenesis of reserpinized bees. Screen for monoamines that are able to equalize the negative impact of reserpine on the workerbee thermogenesis. Injection of octopamine and tyramine lead to significantly increased thorax temperatures of reserpine-fed bees, wheres serotonin and dopamine does not. The solid line represents the mean difference between the thorax temperature $\left(\mathrm{T}_{\mathrm{THX}}\right)$ and ambient temperature $\left(\mathrm{T}_{\mathrm{A}}\right)$ and the shaded area represents the $95 \%$ confidence interval. 
bioRxiv preprint doi: https://doi.org/10.1101/2021.11.04.467276; this version posted November 6, 2021. The copyright holder for this preprint (which was not certified by peer review) is the author/funder, who has granted bioRxiv a license to display the preprint in perpetuity. It is made available under aCC-BY 4.0 International license.

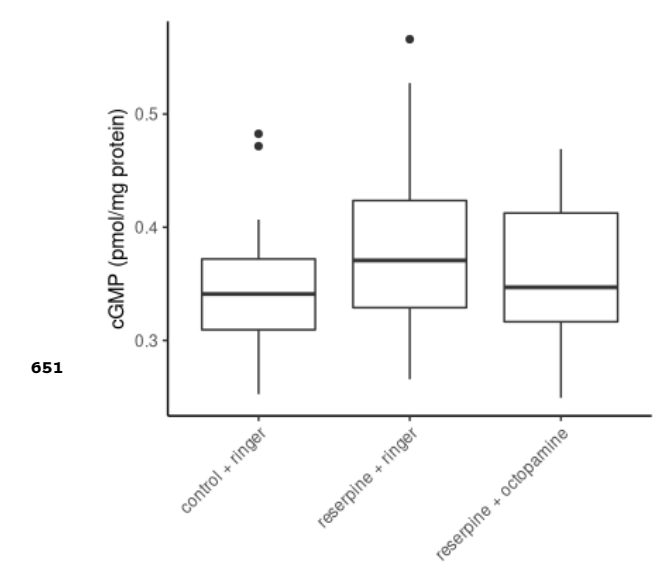

Figure 4-Figure supplement 3. The effect of reserpine on flight muscle cGMP concentrations. Control bees, reserpinized bees and recovered reserpinized bees does not differ in their tissue cGMP concentrations of their flight muscles (Kruskal-Wallis test, $\chi^{2}=2.212, \mathrm{df}=2, \mathrm{p}=0.331$ ). 


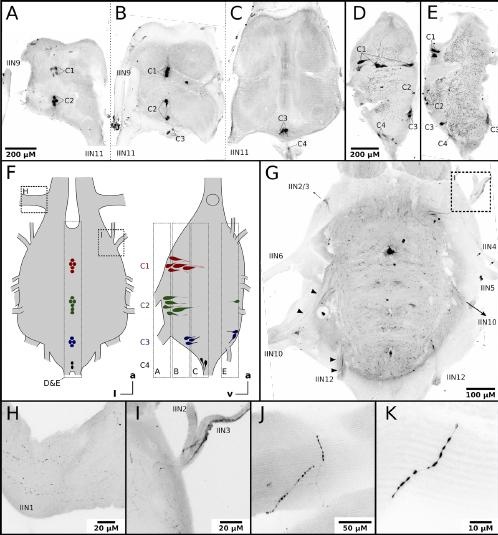

B 


\section{A}

B AmOAR $\alpha 1$

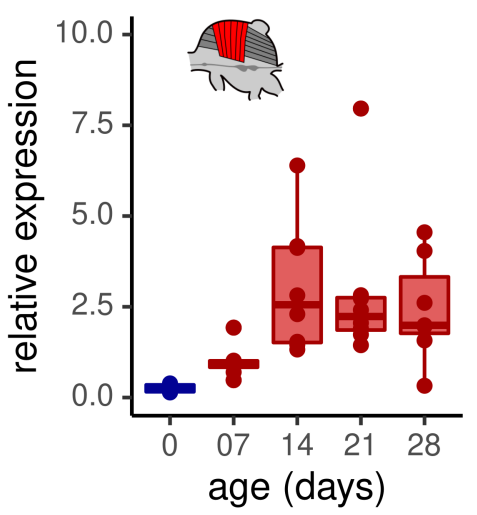

D AmOARß2

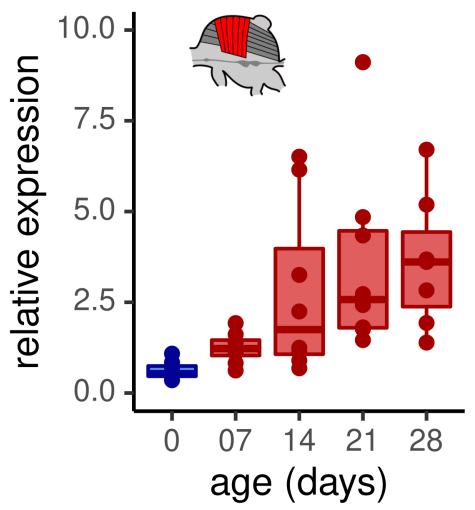

C AmOAR $\alpha 1$

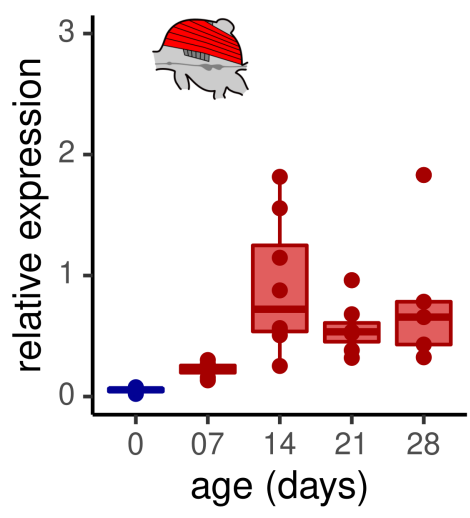

E AmOARB2

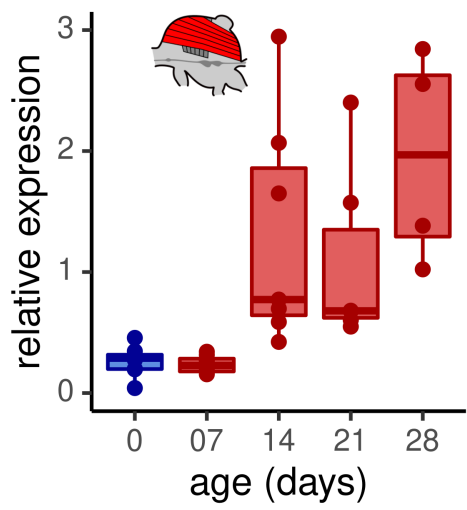




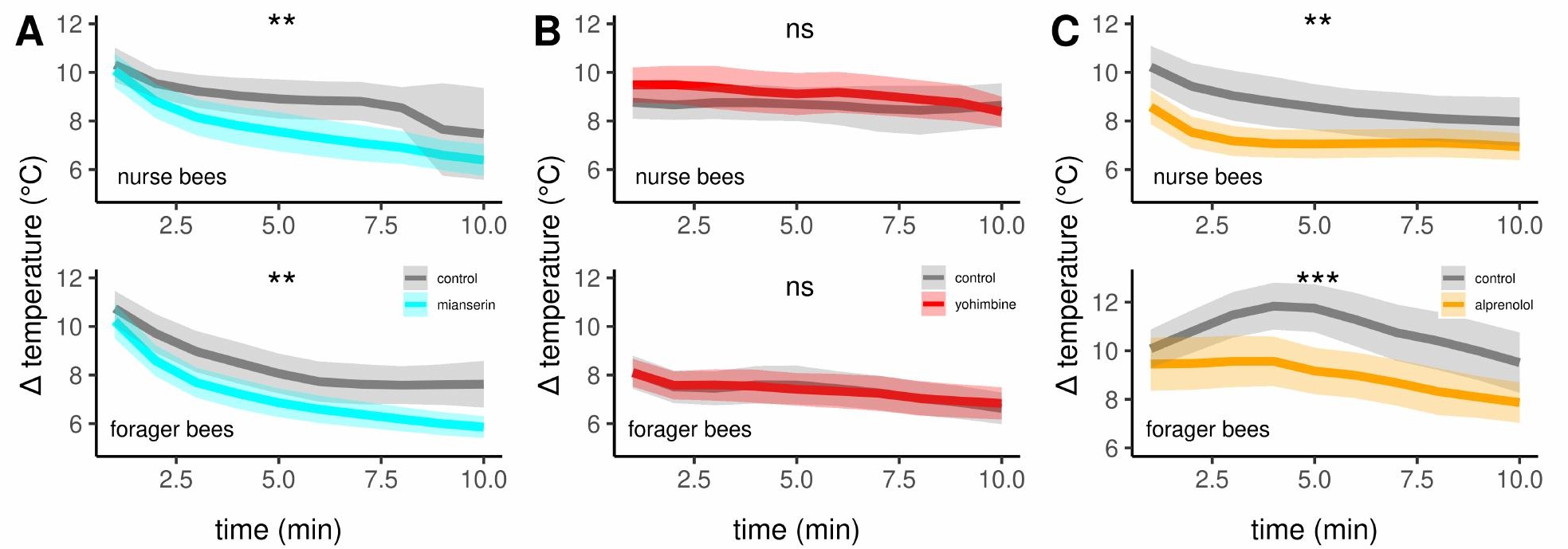


